\title{
Seasonal Dietary Shifts of the Gammarid Amphipod Gondogeneia antarctica in a Rapidly Warming Fjord of the West Antarctic Peninsula
}

\author{
In-Young Ahn ${ }^{1, *}$, Francyne Elias-Piera ${ }^{1,+} \mathbb{D}$, Sun-Yong Ha ${ }^{1}$, Sergio Rossi ${ }^{2,3} \mathbb{D}^{\mathbb{D}}$ and Dong-U Kim ${ }^{1,4}$ \\ 1 Division of Ocean Sciences, Korea Polar Research Institute, 26 Songdomirae-ro, Incheon 21990, Korea; \\ Francyne.ep@gmail.com (F.E.-P.); syha@kopri.re.kr (S.-Y.H.); kimduocean@kopri.re.kr (D.-U.K.) \\ 2 DiSTeBA, University of Salento, Via Monteroni s/n, 73100 Lecce, Italy; sergio.rossi@unisalento.it \\ 3 Instituto de Ciências do Mar-LABOMAR, Universidade Federal do Ceará, Av. da Abolição, \\ Fortaleza 3207, Brazil \\ 4 School of Earth and Environmental Sciences, Seoul National University, Seoul 08826, Korea \\ * Correspondence: iahn@kopri.re.kr \\ † Present address: Instituto Oceanográfico, Universidade de São Paulo, São Paulo 05508-900, Brazil.
}

Citation: Ahn, I.-Y.; Elias-Piera, F.;

Ha, S.-Y.; Rossi, S.; Kim, D.-U.

Seasonal Dietary Shifts of the

Gammarid Amphipod Gondogeneia antarctica in a Rapidly Warming Fjord of the West Antarctic Peninsula. J. Mar. Sci. Eng. 2021, 9, 1447. https:// doi.org/10.3390/jmse9121447

Academic Editor: Chiara Lauritano

Received: 17 November 2021

Accepted: 13 December 2021

Published: 17 December 2021

Publisher's Note: MDPI stays neutral with regard to jurisdictional claims in published maps and institutional affiliations.

Copyright: () 2021 by the authors. Licensee MDPI, Basel, Switzerland. This article is an open access article distributed under the terms and conditions of the Creative Commons Attribution (CC BY) license (https:// creativecommons.org/licenses/by/ $4.0 /)$.

\begin{abstract}
The amphipod Gondogeneia antarctica is among the most abundant benthic organisms, and a key food web species along the rapidly warming West Antarctic Peninsula (WAP). However, little is known about its trophic strategy for dealing with the extreme seasonality of Antarctic marine primary production. This study, using trophic markers, for the first time investigated seasonal dietary shifts of $G$. antarctica in a WAP fjord. We analyzed $\delta^{13} \mathrm{C}$ and $\delta^{15} \mathrm{~N}$ in G. antarctica and its potential food sources. The isotopic signatures revealed a substantial contribution of red algae to the amphipod diet and also indicated a significant contribution of benthic diatoms. The isotope results were further supported by fatty acid (FA) analysis, which showed high similarities in FA composition (64\% spring-summer, $58 \%$ fall-winter) between G. antarctica and the red algal species. G. antarctica $\delta^{13} \mathrm{C}$ showed a small shift seasonally $(-18.9$ to $-21.4 \%$ ), suggesting that the main diets do not change much year-round. However, the relatively high $\delta^{15} \mathrm{~N}$ values as for primary consumers indicated additional dietary sources such as animal parts. Interestingly, G. antarctica and its potential food sources were significantly enriched with $\delta^{15} \mathrm{~N}$ during the fall-winter season, presumably through a degradation process, suggesting that $G$. antarctica consumes a substantial portion of its diets in the form of detritus. Overall, the results revealed that $G$. antarctica relies primarily on food sources derived from benthic primary producers throughout much of the year. Thus, G. antarctica is unlikely very affected by seasonal Antarctic primary production, and this strategy seems to have allowed them to adapt to shallow Antarctic nearshore waters.
\end{abstract}

Keywords: Gondogeneia antarctica; seasonal dietary shift; macroalgae; benthic diatoms; $\mathrm{C}$ and $\mathrm{N}$ stable isotopes; West Antarctic Peninsula; King George Island; Marian Cove $\left(62^{\circ} 13^{\prime} \mathrm{S}\right.$; $\left.58^{\circ} 47^{\prime} \mathrm{W}\right)$

\section{Introduction}

Antarctic marine ecosystems are rapidly changing, particularly along the West Antarctic Peninsula (WAP), due to regional warming and glacier melt [1-4]. The changes are most prominent in shallow coastal waters where marine-terminating glaciers have been rapidly retreating over the last half-century [5]. Aside from the ongoing climate impacts, ice disruptions are prevalent year-round in the intertidal and shallow subtidal zones, and benthic communities end up with low abundance and low diversity [6-8].

Amphipods are one of the few benthic fauna frequently observed in highly disturbed shallow habitats. Vagile amphipods aggregate in gravel or macroalgal beds, utilizing them as shelter and/or potential food sources [9-15]. Amphipod crustaceans are among the most specious fauna, with more than 800 species in the Southern Ocean; $>500$ are strictly endemic to the Antarctic [16] and remarkably abundant along the Antarctic Peninsula $[9,17,18]$. 
Amphipods also show a highly diverse lifestyle associated with a variety of food sources and habitats [13,19-21].

The gammaridean amphipod Gondogeneia antarctica (Chevreux, 1906) is one of the most abundant species, particularly in shallow $(<40 \mathrm{~m})$ nearshore habitats, and is usually associated with macroalgal beds, which frequently form dense canopies in shallow waters along the WAP $[9,11,22-26]$. Nearshore Antarctic benthic communities rely on various food sources obtained through multiple pathways from both pelagic and benthic primary producers [27-31]. G. antarctica feeds primarily on benthic diatoms and macroalgae $[10,13,32,33]$, although its gut contents indicated that it also consumes some animal parts (e.g., crustacean parts and sponge spicules) $[9,10,13,34]$. In turn, this species is preyed upon by various benthic invertebrates and demersal fishes, among other taxonomic groups [26,35-40]. Thus, G. antarctica plays an important role in shallow Antarctic marine food webs [40]. Therefore, the trophic response of G. antarctica to climate change and consequent constraints may be a good indication of the adaptability of this species, as well as of trophically related key organisms.

However, little is known about the trophic strategy of G. antarctica for dealing with the extreme seasonality in primary production of the Antarctic marine environment, and almost all feeding studies have been carried out during the summer when food availability is highest. A prerequisite to evaluate the adaptations or constraints of a key species to climate change is to understand its seasonal trophic characteristics (e.g., feeding preferences and the ability to mobilize energy during food-constrained periods). The Antarctic marine environment is characterized by small seasonal variations in seawater temperature and salinity, whereas primary phytoplankton production is extremely seasonal with explosive blooms occurring during a relatively short time in summer [41].

In this study, using trophic markers, we for the first time investigated dietary shifts in G. antarctica over 1 year in Marian Cove, a typical nearshore habitat for this species in the WAP. We analyzed carbon and nitrogen stable isotopes (SIs) and fatty acids (FAs) of G. antarctica along with its potential food sources (macroalgae, benthic diatoms, and suspended particulate organic matter (SPOM)), and examined any seasonal shifts in their trophic signatures. The findings from this study will enhance our understanding of the G. antarctica trophic strategy to deal with extremely seasonal food availability in its habitat and provide insight into likely future changes in the trophic relationships of nearshore benthic communities in the WAP.

\section{Materials and Methods}

\subsection{Study Area}

The King Sejong Station $\left(62^{\circ} 13^{\prime} \mathrm{S}, 58^{\circ} 47^{\prime} \mathrm{W}\right)$ is located in Marian Cove, which is a glacial embayment (4.5 km long, $\sim 1.5 \mathrm{~km}$ wide, $\sim 130 \mathrm{~m}$ deep) within Maxell Bay bounded by the Weaver Peninsula and Barton Peninsula (Figure 1). Surface seawater freezes frequently in winter, although not every year, with variable cover of drifting ice throughout much of the year. Seawater temperature varies seasonally, from a maximum of ca. $+1.5^{\circ} \mathrm{C}$ in February to a minimum of ca. $-1.8^{\circ} \mathrm{C}$ in August; salinity varies much less, from 33.8 to $34.1 \mathrm{psu}$ [42]. Further details of the hydrographic features and other environmental conditions of this area have been described elsewhere [43,44]. 

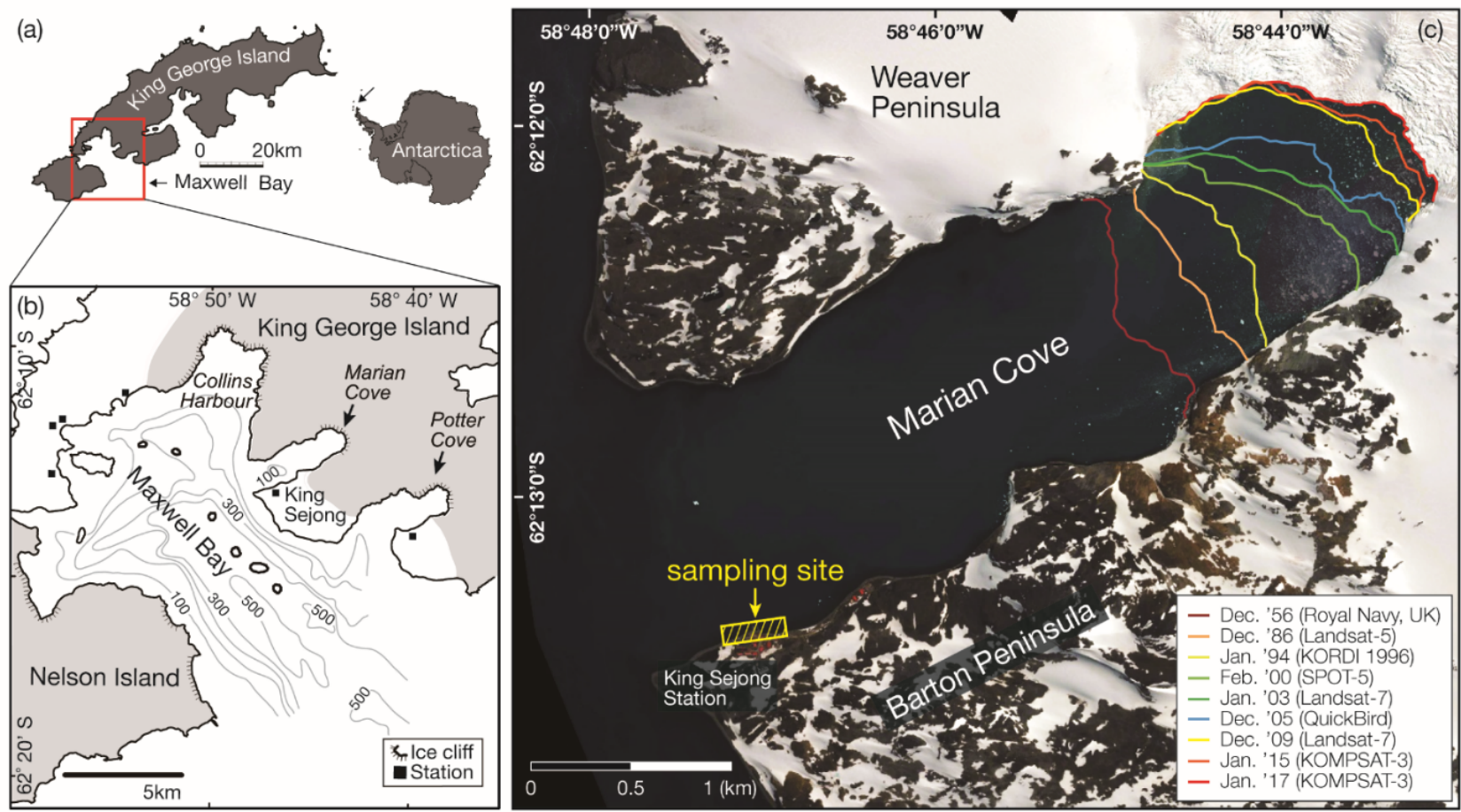

Figure 1. Study area. (a) Location of King George Island and Maxwell Bay. (b) Bathymetry of Maxwell Bay and its tributary embayments. Bathymetric contours are drawn based on information from the Atlas Hidrografico Chileno Antarctica of the Instituto Hidrografico de la Armada, Chile (1982). The gray area indicates glacial cover. (c) The sampling site in Marian Cove (hatched area) and glacier lines since 1956. The figure was adapted from [45] and the glacier lines were updated to December 2017.

Tidewater glaciers are well developed along the fringe of the inner cove, and the glaciers retreated by approximately $1.7 \mathrm{~km}$ from 1956 to 2013 [45]. Recent satellite images show that these glaciers have been continuously retreating since then [42]. Glacial retreat is accompanied by a series of processes (e.g., glacier calving and melting), introducing large volumes of ice, fresh meltwater, and terrigenous sediment to the cove, and eventually generating distinct environmental gradients along with glacial runoff [44,46-49]. Recent studies conducted in the cove have shown that these processes following the glacial retreats have impacted the marine inhabitants, particularly the benthic communities $[42,45,49]$. These previous studies have suggested Marian Cove as a model ecosystem for climaterelated studies.

\subsection{Selection of Potential Food Items for Analysis}

G. antarctica has been known to predominantly rely on macroalgae and microphytobenthos for its main diets $[10,13,32,33]$, despite the presence of a diverse array of food items (e.g., crustacean parts and sponge spicules) in its gut content $[9,10,13,34]$. Macroalgae, benthic diatom, and suspended particulate organic matter (SPOM) were selected primary food sources of $G$. antarctica for this study.

Four species of red algae (Iridaea cordata, Palmaria decipiens, Gigartina skottsbergii, and Curdiea racovitzae) and two species of brown algae (Phaeurus antarcticus and Desmarestia sp.), which are very common in this area [50-53], were collected. The red algae are known to be palatable to many herbivores, detritivores, and omnivores [10,34,54-56]. Benthic diatoms were reported as a primary food source for G. antarctica and other shallow-water amphipod species during austral summer [13,57]. Previous studies in this area have reported widespread and intense benthic diatom blooms in shallow waters, and the benthic diatoms were consumed by a variety of common benthic fauna [30,58]. Other studies in the peninsula region also reported that benthic diatoms associated with macroalgae were consumed selectively or randomly by herbivores, such as amphipods $[13,59]$. 
In addition to macroalgae and benthic diatom, SPOM was also selected as a potential food source, as it likely reflects organic detritus on the bottom, which are available to the amphipods in the study area. In general, SPOM, the most important form of organic particulate matter in the water column, is indicative of pelagic primary production. SPOM eventually settles to the bottom after bloom and constitutes part of sedimentary organic deposit, which is available to benthic fauna. In shallow nearshore waters, however, organic detritus settled on the bottom can be easily resuspended by tides or waves. Previous studies in this area reported that a substantial portion of SPOM in the shallow nearshore waters $(<30 \mathrm{~m})$ was frequently derived from benthic sources, such as benthic diatoms detached from their biotic and abiotic substrates and resuspended by wind-generated vertical mixing [60]. SPOM $\delta^{13} \mathrm{C}$ values reported in a previous study in the same area during austral summer $(-24.1 \pm 0.2 \%, n=6)$ [61] were even close to the benthic diatom values $(-23.3 \pm 0.3 \%$ in [30]), while the reported SPOM $813 \mathrm{C}$ values derived from phytoplankton ranged from -28.0 to $-30.4 \%$ [59]. Thus, findings from previous studies suggest that SPOM in shallow nearshore Antarctic waters could consist of a mixture of organic matter derived from various sources resuspended from the sea floor, and it reflect organic detritus on the bottom available to the amphipods.

\subsection{Sample Collection and Processing}

G. antarctica, SPOM, and macroalgae were collected between January and November 2015 from intertidal and shallow subtidal waters $(<0.5 \mathrm{~m}$ below low tide level) adjacent to the station. To obtain the SPOM, surface seawater was collected using 2 L sterile LDPE collapsible water bottles (DAIHAN, Wonju, South Korea), and the collected water was filtered (300-500 mL for each $\delta^{13} \mathrm{C}$ replicate and $700-1000 \mathrm{~mL}$ for each $\delta^{15} \mathrm{~N}$ replicate) using a vacuum pump onto pre-combusted $\left(450^{\circ} \mathrm{C}, 4 \mathrm{~h}\right)$ glass fiber filters (25-mm in diameter; Whatman, Florham Park, NJ, USA). The filters were immediately frozen.

Macroalgae stranded on the shore were randomly collected by hand in February, March, May, and October but not in winter (June-September), during which the shallow seabed was covered by pack ice. The collected macroalgae seemed to have been recently detached by waves and were fresh at the time of collection onshore. The collected macroalgal fronds were washed with filtered seawater. All visible encrusted fauna and flora were removed from the surface and placed into plastic bags after being cut into pieces, and then frozen. G. antarctica was randomly collected using a hand net $(20 \mathrm{~cm}$ diameter, $100 \mu \mathrm{m}$ mesh) in the shallow subtidal zone $(<50 \mathrm{~cm})$. The collected SPOM, macroalgae, and animals were stored at $-80^{\circ} \mathrm{C}$ for up to 9 months at the station and then transported to the KOPRI for analysis. Isotopic data for benthic diatoms and additional data for macroalgae were obtained from a previous study performed in this area [30].

\subsection{Stable Isotope Analysis (SIA)}

The macroalgae and amphipods were freeze-dried and ground with a mortar and pestle into a homogenous powder at the KOPRI. Aliquots (0.60-0.80 $\mathrm{mg}$ each) of the homogenized samples were used for the SIA. The amphipod samples for each sampling time included both juveniles (body length $<0.9 \mathrm{~cm}$ ) and adults $(>0.9 \mathrm{~cm})$ [10]. Among them the samples with body size $(0.5-1.5 \mathrm{~cm})$ were pooled to ensure a sufficient amount for reliable and representative composite samples.

The samples for the organic carbon isotope analysis were rapidly acidified with two or three drops of $1 \mathrm{~N} \mathrm{HCl}$ to remove inorganic carbonates, and rinsed with Milli-Q water [62]. Because acid washing can affect the nitrogen isotope ratios of organic material [63], samples for the nitrogen isotope analysis were not acidified. Lipids were removed using the chloroform/methanol procedure outlined in [64]. The $\delta^{13} \mathrm{C}$ and $\delta^{15} \mathrm{~N}$ analyses were performed with an isotopic mass spectrometer (Isoprime 100; EIementar, Manchester, UK) coupled with an elemental analyzer (Euro EA3028; EuroVector, Milan, Italy) following the procedure in [30]. 
The isotopic ratios were expressed in parts per thousand (\%o) according to the following equation:

$$
\delta \mathrm{X}=\left[\left(\mathrm{R}_{\text {sample }} / \mathrm{R}_{\text {standard }}\right)-1\right] \times 10^{3}
$$

where $X$ is ${ }^{13} \mathrm{C}$ or ${ }^{15} \mathrm{~N}$ and $\mathrm{R}$ is the corresponding ${ }^{13} \mathrm{C} /{ }^{12} \mathrm{C}$ or ${ }^{15} \mathrm{~N} /{ }^{14} \mathrm{~N}$ ratio. The $\mathrm{R}_{\text {standard }}$ values for ${ }^{13} \mathrm{C}$ and ${ }^{15} \mathrm{~N}$ are from V-PDB and atmospheric $\mathrm{N}_{2}$, respectively.

\subsection{Fatty Acid (FA) Analysis in Gondogeneia antarctica and Red Algae}

FAs were determined using a protocol slightly modified from those used in previous studies [65-67]. Aliquots (approximately $15 \mathrm{mg}$ ) of freeze-dried and homogenized amphipod and red algal samples were extracted with a mixture of dichloromethane: methanol (3:1, $v: v)$. The extract was separated into three fractions (neutral lipids, free fatty acids (FFAs), and polar lipids) by column chromatography using an aminopropyl mini-column (Waters Sep-Pak ${ }^{\circledR}$ Cartridges; Waters Inc.; Milford, MA, USA). The FFA fraction was methylated with $20 \%$ BF3 in methanol $\left(90{ }^{\circ} \mathrm{C}\right.$ for $\left.1 \mathrm{~h}\right)$, and the FAs were recovered as fatty acid methyl esters (FAMEs). The FAMEs were analyzed by gas chromatography (Agilent 5890 Series II; Agilent Technology Inc.; Santa Clara, CA, USA) equipped with a flame ionization detector. The FAMEs were identified and quantified based on retention times and a calibration curve using external standards (37 Component FAME Mix C4-C24; Supelco, Bellefonte, PA, USA). The peaks areas of each compound were integrated using ChromQuest 4.1 software, and total FA content $\left(\mu \mathrm{g} \cdot \mathrm{mg}^{-1}\right)$ and composition $(\%)$ were determined.

\subsection{Data Analysis and Statistics}

Seasonal trends in the environmental parameters were analyzed by regression analysis using PASW Statistics (version 18.0; SPSS Inc.; Chicago, IL, USA). Univariate nonparametric (Kruskal-Wallis test and the Mann-Whitney $U$ test) and correlation analyses were also performed using PASW. Multivariate analyses were performed using PRIMER version 6 [68]. We tested for differences in FA composition between the amphipod and red algal groups, and between the amphipod groups during different seasons using the analysis of similarity (ANOSIM). Similarities between the groups were further identified in a non-metric multi-dimensional scaling (MDS) ordination plot based on the Bray-Curtis similarity index. The relative contributions of the FAs to the similarity/dissimilarity identified in the MDS plot were analyzed using the similarity percentages program (SIMPER).

\subsection{Supporting Data}

Seawater temperature, as well as salinity and chlorophyll (Chl) data, were obtained from year-round monitoring at the station [69].

\section{Results}

\subsection{Seasonal Variations in Salinity, Seawater Temperature, and Chl-a Concentrations}

Salinity (psu) varied slightly (32.6 to 34.4), with a small decline seen during the summer months due to meltwater input (Figure 2a). In contrast, seawater temperature exhibited distinct variation $\left(+1.97\right.$ to $\left.-1.87^{\circ} \mathrm{C}\right)$ over the year, with the lowest monthly average occurring in September $\left(-1.85^{\circ} \mathrm{C}\right)$ and the highest in February $\left(1.49^{\circ} \mathrm{C}\right)$ (Figure $\left.2 \mathrm{~b}\right)$. The seawater was frozen (sea ice thickness up to $1.5 \mathrm{~m}$, personal observation) for approximately 3 months from June 21 through October 2. During this period, the temperature was almost stable, remaining at the seawater freezing point $\left(-1.8^{\circ} \mathrm{C}\right)$.

Chl- $a$ concentrations in the surface seawater peaked several times during summer (January-March) with the highest monthly average occurring in January $\left(0.64 \mu \mathrm{g} \cdot \mathrm{L}^{-1}\right)$ (Figure $2 \mathrm{c})$. The highest daily peak $\left(1.28 \mu \mathrm{g} \cdot \mathrm{L}^{-1}\right)$ occurred on February 25. In addition, unusually late blooms occurred in May (monthly mean $=0.48 \mu \mathrm{g} \cdot \mathrm{L}^{-1}$ with several daily peaks of $\left.\sim 1.05 \mu \mathrm{g} \cdot \mathrm{L}^{-1}\right)$. Thereafter, Chl- $a$ concentrations declined sharply and remained at very low levels $\left(<0.1 \mu \mathrm{g} \cdot \mathrm{L}^{-1}\right)$ during winter (June-August), with the lowest monthly average occurring in July $\left(0.046 \mu \mathrm{g} \cdot \mathrm{L}^{-1}\right)$. The Chl- $a$ values started to increase again in early September, reaching levels similar to summer during late November $\left(0.64-0.67 \mu \mathrm{g} \cdot \mathrm{L}^{-1}\right)$. 
Overall, the variation in Chl- $a$ closely followed the variation in seawater temperature $(\mathrm{r}=0.66, n=66, p<0.001)$, while salinity was negatively correlated with temperature $(\mathrm{r}=-0.67, n=266, p<0.001)$.

(a) Salinity (psu)

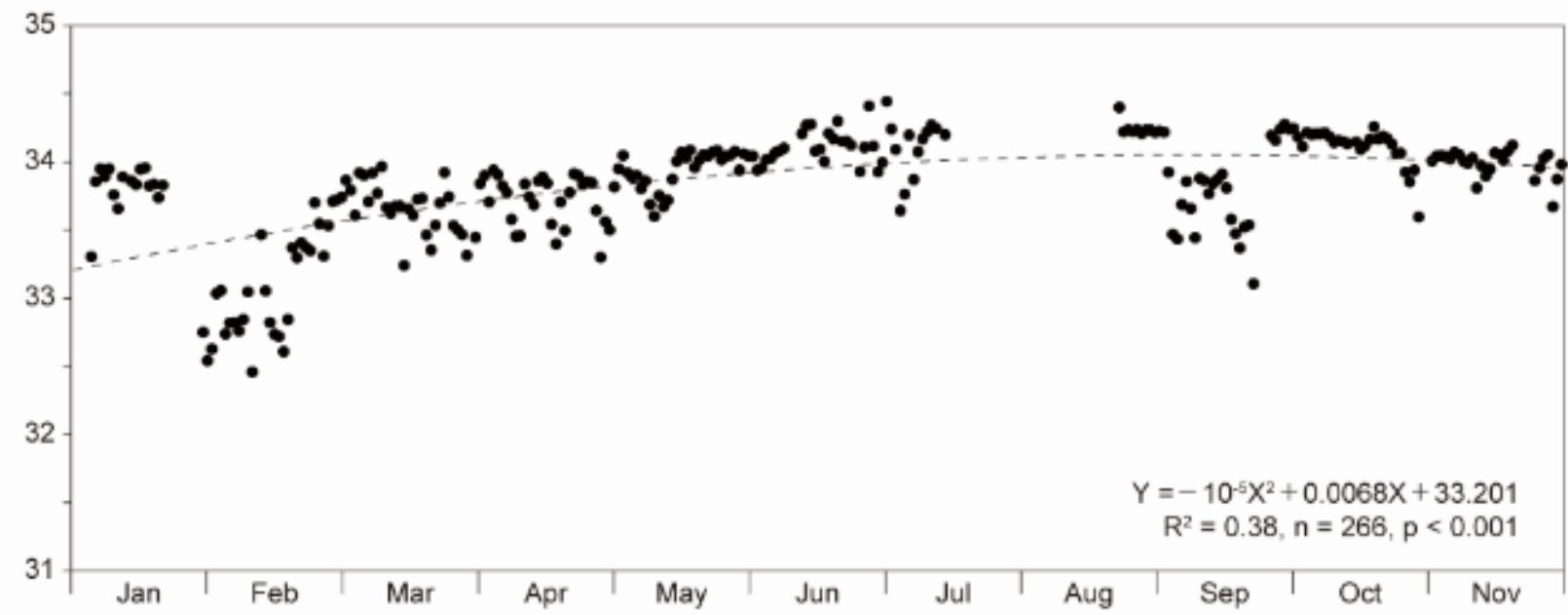

(b) Temperature $\left({ }^{\circ} \mathrm{C}\right)$

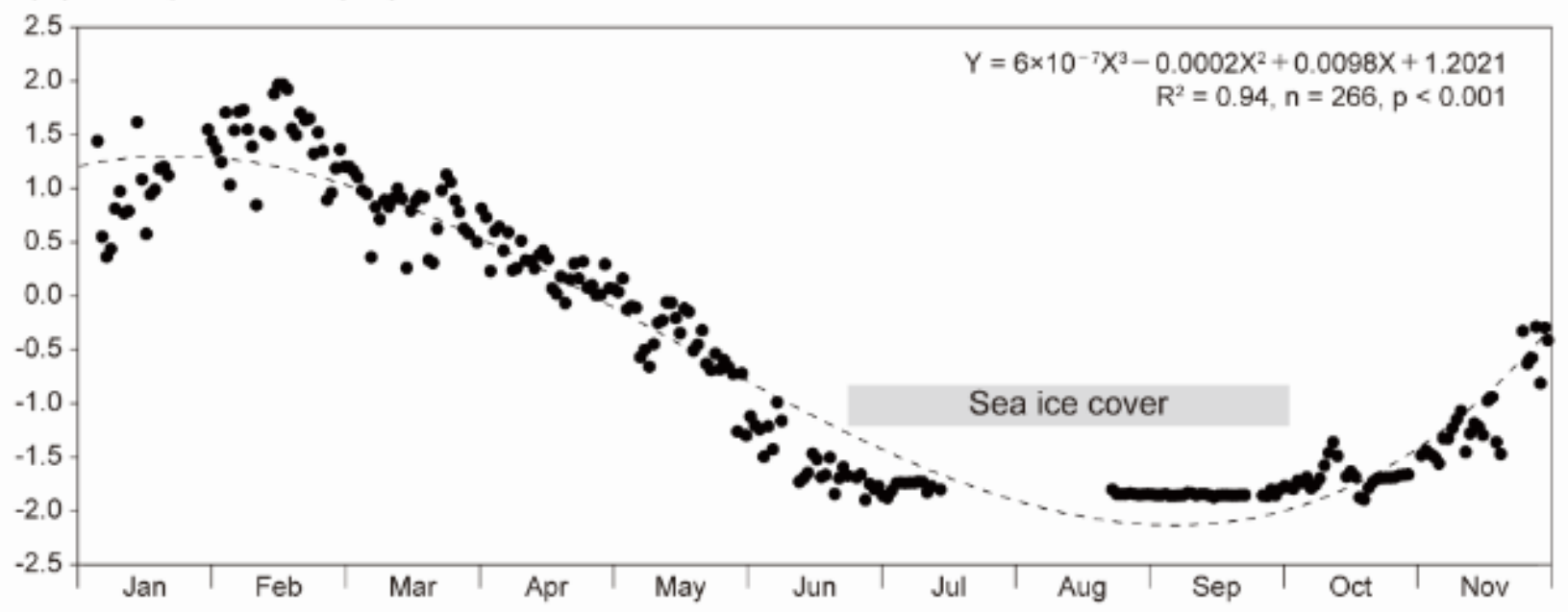

(c) Chlorophyll-a $(\mu \mathrm{g} / \mathrm{l})$

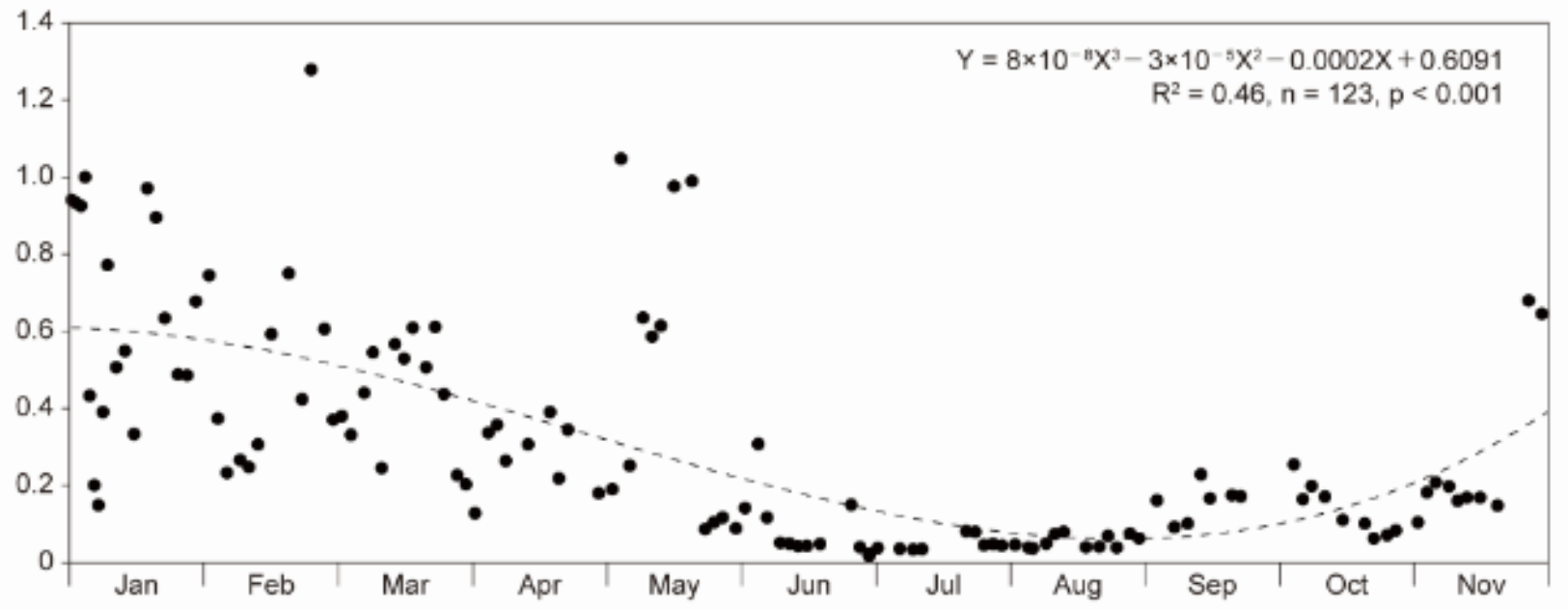

Figure 2. Seasonal variations in the surface seawater at the Marian Cove sampling site in 2015. 
3.2. Seasonal Variations in the Isotopic Signatures of Gondogeneia antarctica and Its Potential Food Sources

Seasonal variations in $\delta^{13} \mathrm{C}$ and $\delta^{15} \mathrm{~N}$ values for G. antarctica and SPOM are displayed in Figure $3 \mathrm{a}-\mathrm{d}$. The monthly average $\delta^{13} \mathrm{C}$ and $\delta^{15} \mathrm{~N}$ values for $\mathrm{G}$. antarctica, and its potential food sources during different months, are summarized in Table 1.

(a) $\delta^{13} \mathrm{C}$ of Gondogeneia antarctica

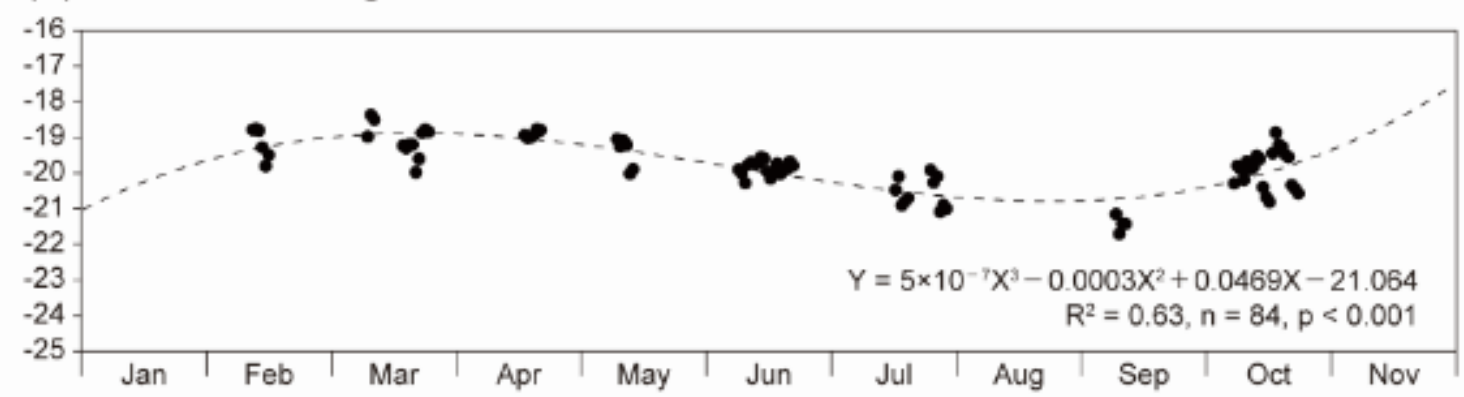

(b) $\delta^{15} \mathrm{~N}$ of Gondogeneia antarctica

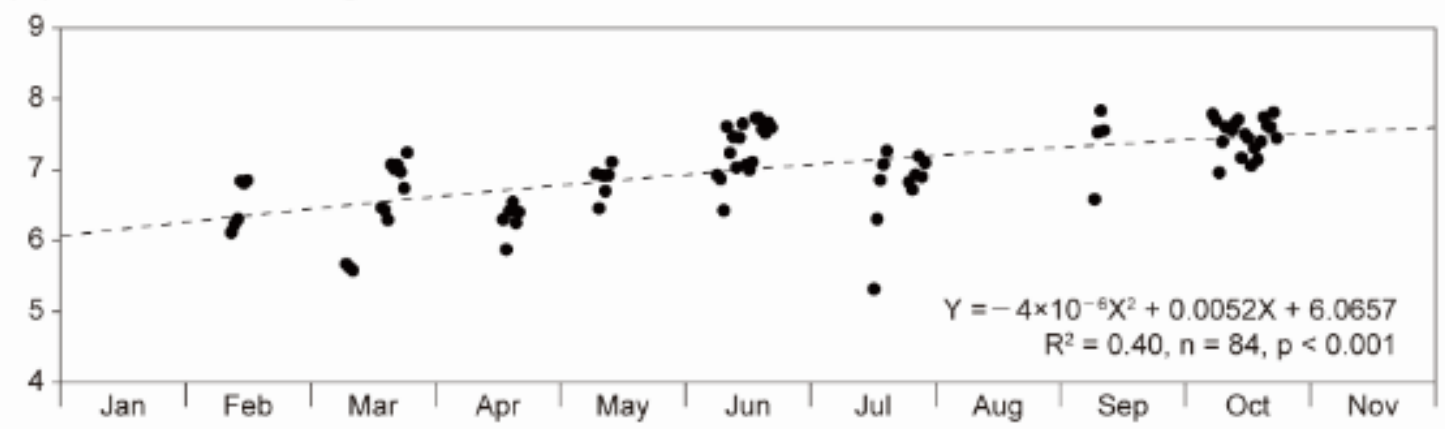

(c) $\delta^{13} \mathrm{C}$ of SPOM

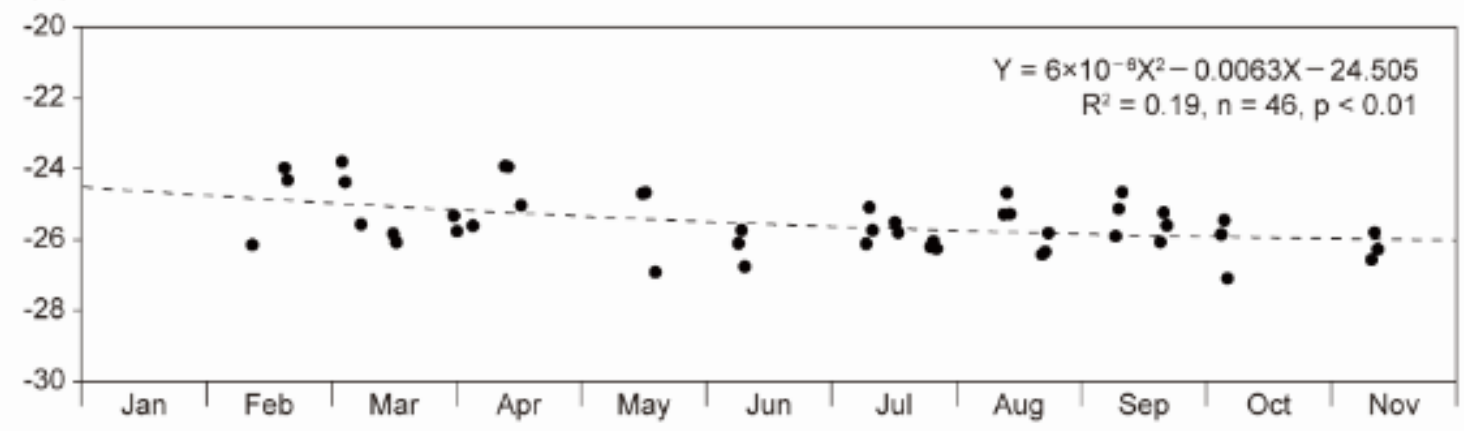

(d) $\delta^{15} \mathrm{~N}$ of SPOM

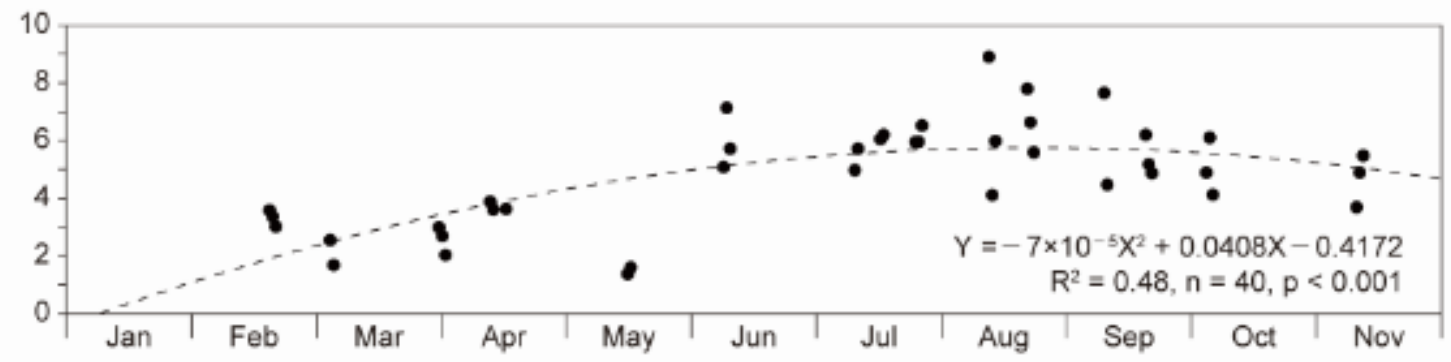

Figure 3. Seasonal variations in the $\delta^{13} \mathrm{C}$ and $\delta^{15} \mathrm{~N}$ values for Gondogeneia antarctica $(\mathbf{a}, \mathbf{b})$ and suspended particulate organic matter (SPOM) (c,d) in the surface water of the sampling site in 2015. 
Table 1. $\mathrm{C}$ and $\mathrm{N}$ stable isotopic ratios of the amphipod Gondogeneia antarctica and its potential food sources in various months. $n$, replicate numbers for the $\delta^{13} \mathrm{C}$ and $\delta^{13} \mathrm{~N}$ analyses, except those indicated for SPOM $\delta^{15} \mathrm{~N}$ values. Numbers in parentheses for G. antarctica indicate the total number of individuals pooled for analysis. Mean and standard deviation (SD) values are presented. R: red algae; Br: brown algae. $n$ : replicates of analysis. The data with * was cited from [30].

\begin{tabular}{|c|c|c|c|c|c|c|c|}
\hline \multirow{2}{*}{ Specimens } & \multirow{2}{*}{ Month } & \multirow{2}{*}{$n$} & \multicolumn{2}{|c|}{$\delta^{13} \mathrm{C}(\%)$} & \multicolumn{2}{|c|}{$\delta^{15} N(\%)$} & \\
\hline & & & Mean & SD & Mean & SD & \\
\hline \multirow{8}{*}{ Gondogeneia antarctica } & Feb & $6(137)$ & -19.2 & 0.44 & 6.53 & 0.35 & \\
\hline & Mar & $12(174)$ & -19.1 & 0.45 & 6.52 & 0.61 & \\
\hline & Apr & $6(107)$ & -18.9 & 0.10 & 6.30 & 0.23 & \\
\hline & May & $6(151)$ & -19.4 & 0.42 & 6.85 & 0.23 & \\
\hline & Jun & $18(449)$ & -19.9 & 0.19 & 7.32 & 0.37 & \\
\hline & Jul & $11(94)$ & -20.6 & 0.42 & 6.78 & 0.55 & \\
\hline & Sep & $4(27)$ & -21.4 & 0.23 & 7.38 & 0.55 & \\
\hline & Oct & $21(598)$ & -19.9 & 0.53 & 7.49 & 0.24 & \\
\hline \multirow[t]{10}{*}{ SPOM } & Feb & 3 & -24.8 & 1.17 & 3.32 & 0.29 & \\
\hline & Mar & 5 & -25.1 & 0.99 & 2.12 & 0.61 & \\
\hline & Apr & 6 & -24.9 & 0.81 & 3.14 & 0.70 & \\
\hline & May & 3 & -25.4 & 1.29 & 1.48 & 0.16 & $(n=2)$ \\
\hline & Jun & 3 & -26.2 & 0.52 & 5.98 & 1.05 & \\
\hline & Jul & 8 & -25.8 & 0.40 & 5.91 & 0.48 & $(n=7)$ \\
\hline & Aug & 6 & -25.6 & 0.68 & 6.50 & 1.69 & \\
\hline & Sep & 6 & -25.4 & 0.52 & 5.68 & 1.28 & $(n=5)$ \\
\hline & Oct & 3 & -26.1 & 0.85 & 5.04 & 1.00 & \\
\hline & Nov & 3 & -26.2 & 0.39 & 4.69 & 0.91 & \\
\hline \multirow{3}{*}{$\begin{array}{c}\text { Macroalgae } \\
\text { Iridaea cordata }(\mathrm{R})\end{array}$} & & & & & & & \\
\hline & Mar & 2 & -19.4 & 2.69 & 5.21 & 0.26 & \\
\hline & May & 4 & -23.1 & 2.00 & 5.03 & 0.39 & \\
\hline \multirow[t]{3}{*}{ Palmaria decipiens (R) } & May & 1 & -19.4 & & 5.12 & & \\
\hline & Oct & 2 & -22.3 & 2.65 & 4.18 & 0.06 & \\
\hline & Jan * & 2 & -23.1 & 0.94 & 3.33 & 0.75 & \\
\hline \multirow[t]{3}{*}{ Gigartina skottsbergii (R) } & May & 1 & -21.1 & & 4.90 & & \\
\hline & Oct & 1 & -23.4 & & 3.55 & & \\
\hline & $\operatorname{Jan} *$ & 2 & -23.1 & 1.32 & 3.26 & 0.36 & \\
\hline \multirow[t]{2}{*}{ Curdiea racovitzae $(\mathrm{R})$} & May & 1 & -17.4 & & 5.87 & & \\
\hline & Jan * & 2 & -14.2 & 0.63 & 4.46 & 0.44 & \\
\hline Phaeurus antarcticus (Br) & May & 2 & -32.0 & 1.22 & 2.78 & 0.06 & \\
\hline Desmarestia sp. (Br) & Oct & 1 & -27.3 & & 3.45 & & \\
\hline Benthic diatom & Jan * & 3 & -23.3 & 0.26 & 3.55 & 0.30 & \\
\hline
\end{tabular}

The G. antarctica $\delta^{13} \mathrm{C}$ values (monthly averages: $\max =-18.9 \%$ in April, $\min =-21.4 \%$ in September) were positively correlated with seawater temperature (Pearson's correlation coefficient, $\mathrm{r}=0.67, n=84, p<0.001)$ and the Chl- $a$ concentration $(\mathrm{r}=0.62, n=84, p<0.001)$. The overall variations were small but showed more significant enrichment (Mann-Whitney $U$-test, $p<0.001)$ during the summer-early fall period (February-April) $(-19.1 \pm 0.4 \%$, $n=24)$ than during the fall-winter period (May-September) $(-20.2 \pm 0.7 \%, n=39)$. In contrast, the G. antarctica $\delta^{15} \mathrm{~N}$ value $(6.3 \%$ in April to $7.5 \%$ in October) was negatively correlated with seawater temperature $(\mathrm{r}=-0.60, n=84, p<0.001)$ and Chl- $a$ concentrations $(\mathrm{r}=-0.47, n=84, p<0.001)$, with significant enrichment $(p<0001)$ seen in the winterspring period (May-October) $(7.2 \pm 0.5 \%, n=60)$ compared to the summer-fall period (February-April) $(6.5 \pm 0.4 \%, n=24)$.

The seasonal variation patterns in SPOM $\delta^{13} \mathrm{C}$ and $\delta^{15} \mathrm{~N}$ (Figure $3 c, d$ ) were similar to those of $G$. antarctica. The SPOM $\delta^{13} \mathrm{C}$ showed a small but significant variation over the year (monthly means $=-24.8 \%$ to $-26.2 \%$ ) and was positively correlated with seawater temperature (Pearson's correlation coefficient $(\mathrm{r})=0.43, n=46, p<0.01$ ) and Chl- $a$ concentrations $(\mathrm{r}=0.36, n=46, p<0.05)$. In contrast, the SPOM $\delta^{15} \mathrm{~N}$ values $(1.5 \%$ to $6.5 \%$ o) were negatively correlated with seawater temperature $(\mathrm{r}=-0.74, n=40, p<0.001)$ 
and Chl- $a$ concentrations $(\mathrm{r}=-0.78, n=40, p<0.001)$. The SPOM $\delta^{15} \mathrm{~N}$ value showed a relatively large $(p<0.001)$ increase in the winter season (June-September) $(6.1 \pm 0.9 \%$, $n=21)$ compared to the summer-fall period (February-April) $(3.0 \pm 0.7 \%, n=11)$. The SPOM $\delta^{15} \mathrm{~N}$ value sharply declined in May, during which unusual Chl-a peaks occurred.

Isotopic values of macroalgae were compared only for the two contrasting seasons (May vs. January, March, and October), as sampling was impossible during the winter season (June-September), due to the formation of sea ice (pack ice, fast ice) in the sampling site. The macroalgae $\delta^{13} \mathrm{C}$ values varied widely among species, particularly between red and brown algae. Within the red algal species, C. racovitzae ( -15.6 to $-17.4 \%$, ) was much more enriched with $\delta^{13} \mathrm{C}(p<0.001)$ than the other three species (I. cordata -21.3 to $-22.3 \%$, P. decipiens -19.4 to $-20.5 \%$, and G. skottsbergii -21.1 to $-23.4 \%$ ). The brown algae Desmarestia sp. and P. antarcticus were most depleted with $\delta^{13} \mathrm{C}$ and $\delta^{15} \mathrm{~N}$ (Desmarestia sp. $-27.3 \%$ and $3.5 \%$, P. antarcticus $-32.0 \%$ and $2.8 \%$ ). The macroalgae $\delta^{13} \mathrm{C}$ varied little seasonally, despite the wide variation among species. On the other hand, the macroalgae $\delta^{15} \mathrm{~N}$ values were significantly (Mann-Whitney $U$-test, $p=0.008)$ enriched in May $(5.1 \pm 0.4 \%$, $n=7)$ compared to the other months (January, March, and October) $(4.0 \pm 0.8 \%, n=11)$.

\subsection{Isotopic Signatures of Gondogeneia antarctica and Its Potential Food Sources}

The $\delta^{13} \mathrm{C}$ and $\delta^{15} \mathrm{~N}$ signatures of G. antarctica and its potential carbon sources are displayed in a dual plot (Figure 4). The amphipod and groups of potential food sources (SPOM, red algae, brown algae, and benthic diatoms) during different months were well distinguished by their $\delta^{13} \mathrm{C}$ and $\delta^{15} \mathrm{~N}$ values. The monthly G. antarctica $\delta^{13} \mathrm{C}$ values ranged from -18.9 to $-21.4 \%$, which were close to those of three red algal species $(-19.4$ to $-23.4 \%$ o) and benthic diatom $(-23.3 \%$ ). On the other hand, the SPOM (monthly means $=-24.8 \%$ o to $-26.2 \%$ ) and the brown algae (Desmarestia sp. $-27.3 \%$ and P. antarcticus $-32.0 \%$ ) exhibited far more depleted $\delta^{13} \mathrm{C}$ values.

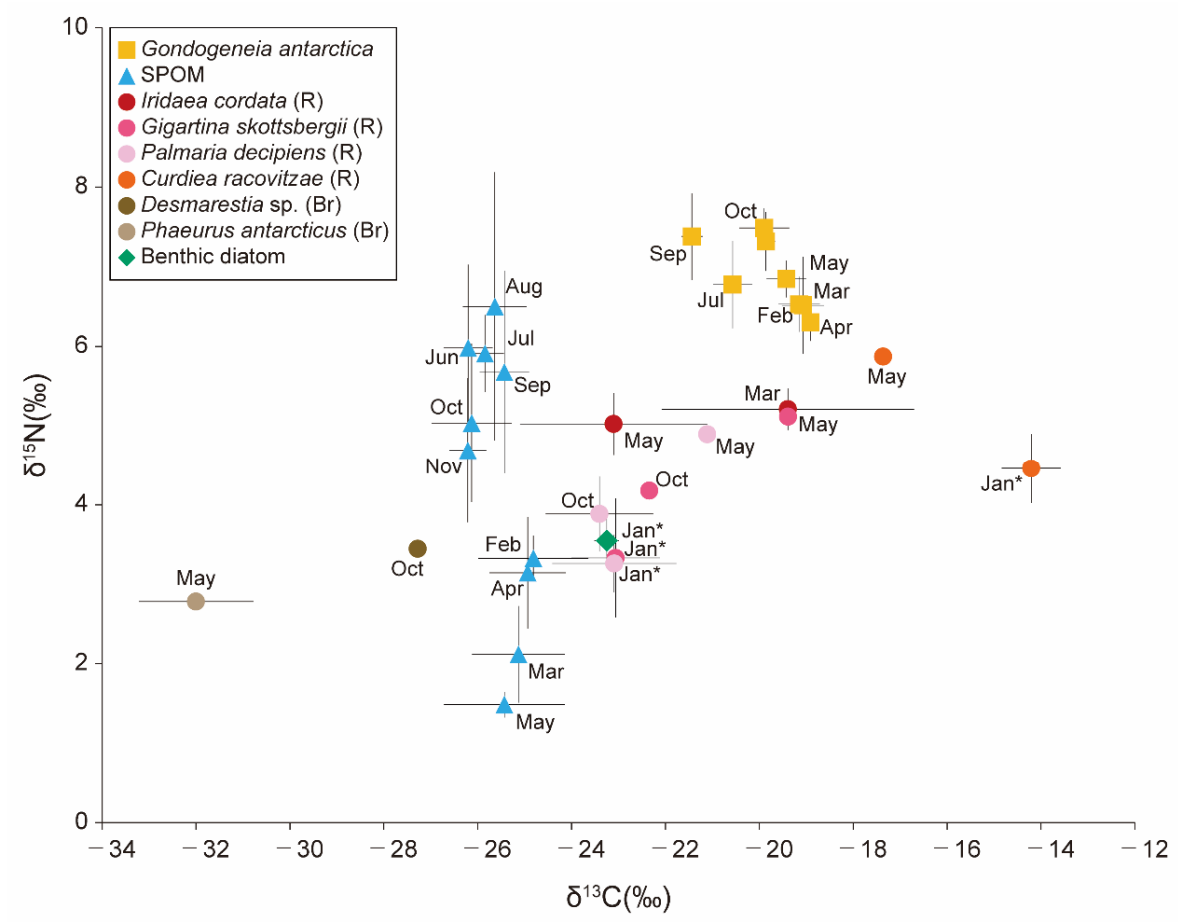

Figure 4. Seasonal variations in the $\delta^{13} \mathrm{C}$ and $\delta^{15} \mathrm{~N}$ values of Gondogeneia antarctica and its potential food sources (suspended particulate organic matter, SPOM; red algae, R, and brown algae, $\mathrm{Br}$ ). Sampling was conducted from February to November 2015. The data for benthic diatom and additional data for macroalgae (* marked) were obtained from a previous study performed in the study area [30]. Mean \pm standard deviation values are presented. Refer to Table 1 for details. 


\subsection{Total FA Content and Composition in Gondogeneia antarctica and Red Algae}

The FA contents and composition of G. antarctica and its presumptive major diet, red algae are shown in Table 2. The most dominant FAs in the amphipod throughout the year were C16:0 (mean $=26.2 \%$ in June, 33.5\% in March), followed by C20:5 $5_{(n-3)}(14.6 \%-23.9 \%)$, $\mathrm{C} 18: 2_{(n-6)}(10.6 \%-15.3 \%), \mathrm{C} 18: 1_{(n-9)}(7.0 \%-11.8 \%), \mathrm{C} 16: 1_{(n-9)}(4.6 \%-10.3 \%)$, and C22:6 $6_{(n-3)}$ $(3.5 \%-5.5 \%)$.

The total FA contents in G. antarctica continued to increase from mid-summer (February) until reaching a peak in May $\left(60.5 \pm 22.1 \mu \mathrm{g} \cdot \mathrm{mg}^{-1} \mathrm{dw}, n=6\right)$. The total remained at similar levels during the winter season and then declined to its lowest level in October $\left(23.2 \pm 7.8 \mu \mathrm{g} \cdot \mathrm{mg}^{-1} \mathrm{dw}, n=13\right)$ (Figure 5a). Among the major FAs, C16:0 and C20:5 $5_{(n-3)}$ showed relatively large variations. Of note, $\mathrm{C} 20: 5_{(n-3)}$ distinctly increased in the winter period in terms of both the absolute and relative composition. (Figure $5 b, c$ ). C16:0 and $\mathrm{C} 18: 1_{(n-9)}, \mathrm{C} 20: 5_{(n-3)}$, and C20:4 $4_{(n-6)}$ were the major FAs in the red algae analyzed in this study. However, the FA composition varied among algal species. C16:0 and C18:1 $1_{(n-9)}$ were most abundant in I. cordata and P. decipiens, while C16:0 and C20:5 $5_{(n-3)}$ were detected as the most dominant in G. skottsbergii and C. racovitzae, respectively.

(a) Total FA $\left(\mathrm{mg} \cdot \mathrm{g}^{-1} \mathrm{dw}\right)$

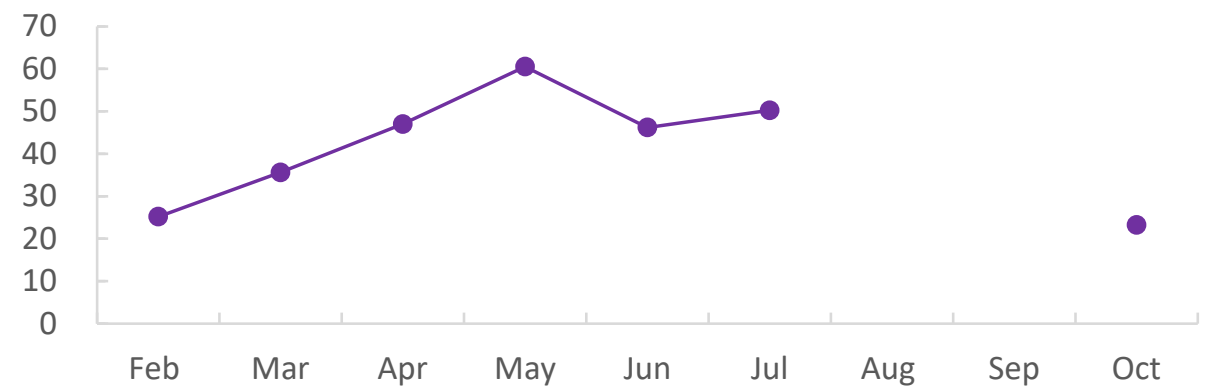

(b) Major FAs $\left(\mathrm{mg} \cdot \mathrm{g}^{-1} \mathrm{dw}\right)$

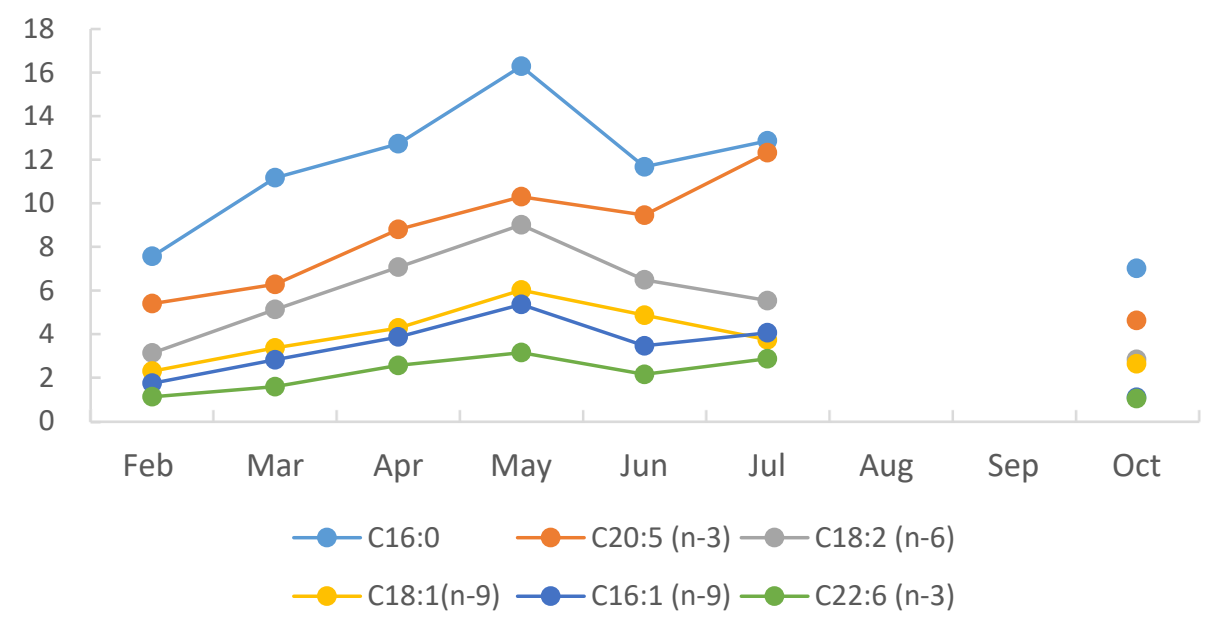

Figure 5. Cont. 


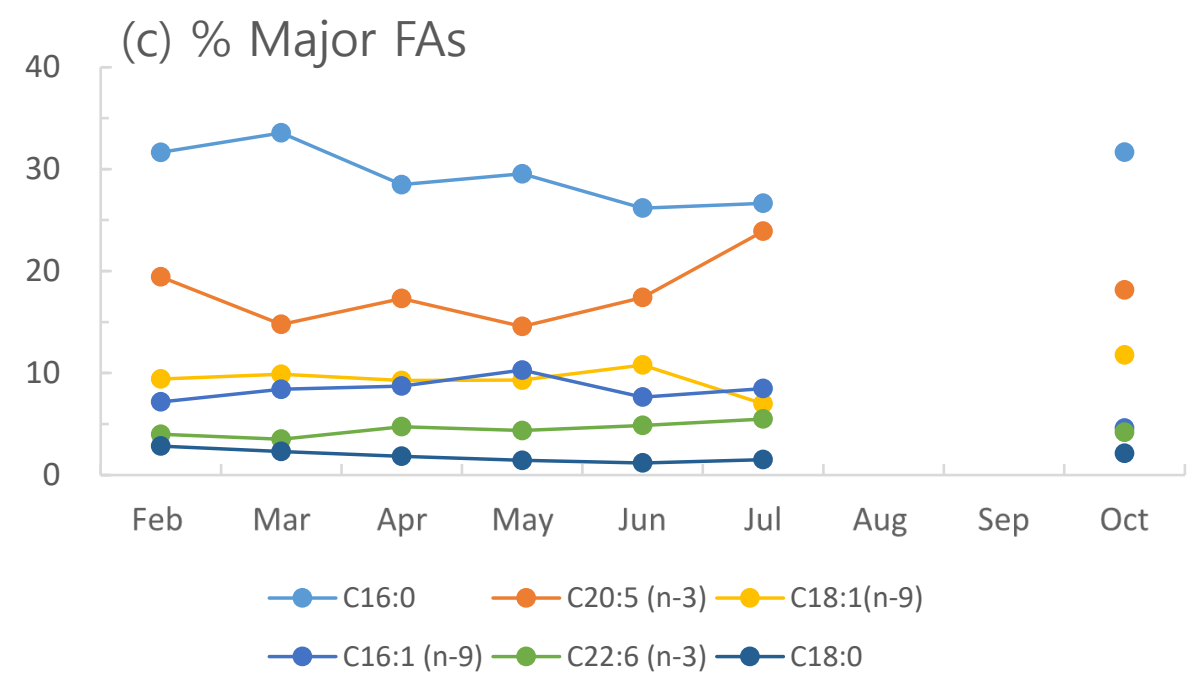

Figure 5. Seasonal variations in the Gondogeneia antarctica fatty acids (FAs). (a) Total contents; (b) absolute concentration of major FAs; (c) \% composition of the major FAs. Mean values are presented. Refer to Table 2 for details.

Nonparametric MDS analysis (Figure 6) revealed that a small but distinct shift in G. antarctica FA composition occurred from spring-summer (February, October) to fall-winter (March, April, June, and July) (ANOSIM test: Global R $=0.17, p=0.014$ ). The MDS plot also showed that the spring-summer composition was closer to the red algal FA composition. The SIMPER analysis (Table 3) showed that the dissimilarity between the amphipod and red algae FA compositions decreased slightly from $42 \%$ during fall-winter to $36 \%$ during spring-summer.

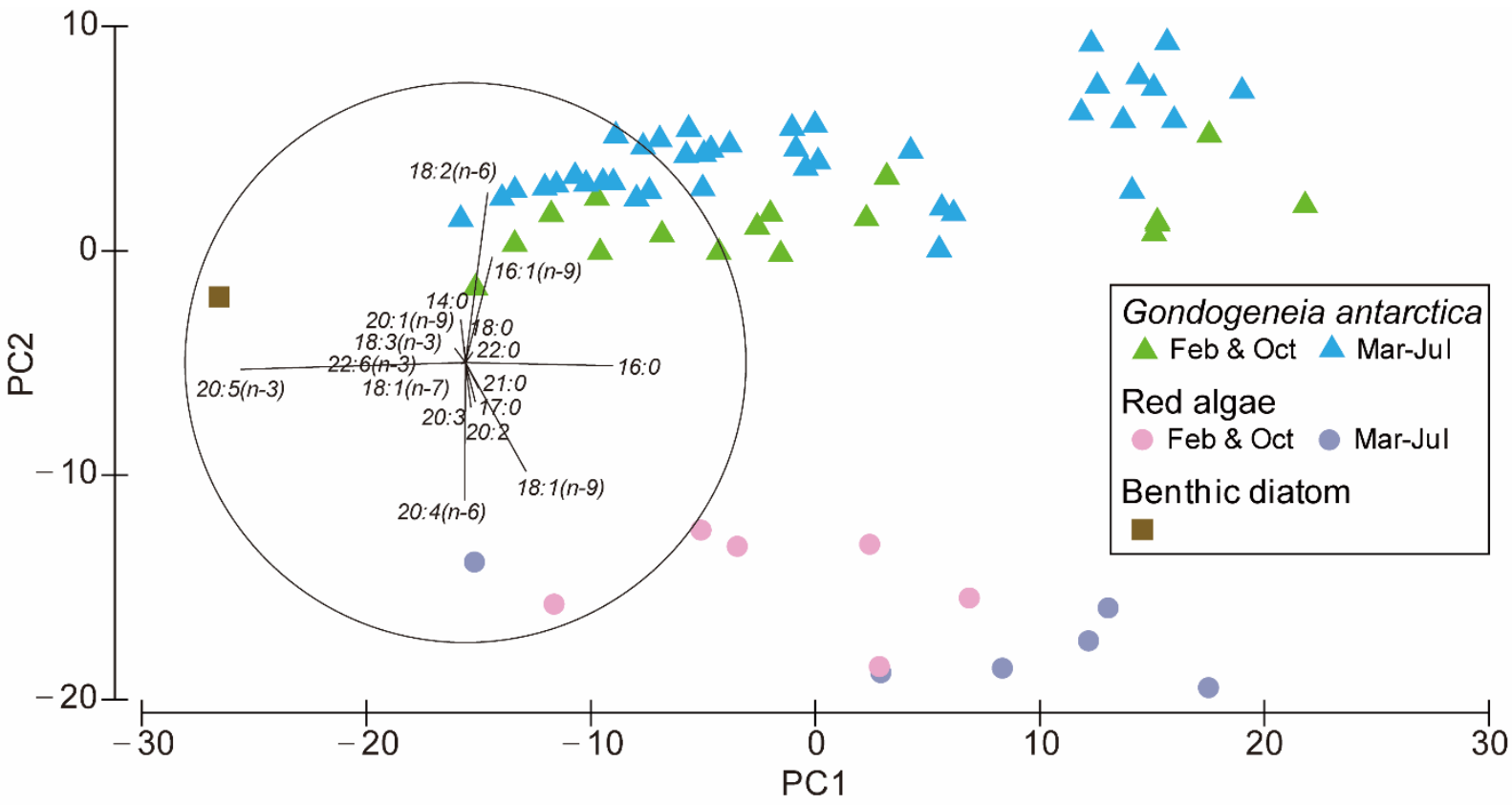

Figure 6. Non-parametric multidimensional scaling (MDS) based on the Bray-Curtis similarity matrix for the fatty acid (FA) compositions of Gondogeneia antarctica and red algae during the two contrasting seasons. Small but distinct differences in the FA composition were detected in G. antarctica between the spring-summer (February and October) and fall-winter (March-July). The FA composition of G. antarctica was closer to the red algal FA composition during spring-summer than early winter (March-May). Benthic diatom data are from [13]. 


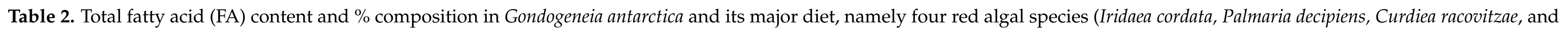

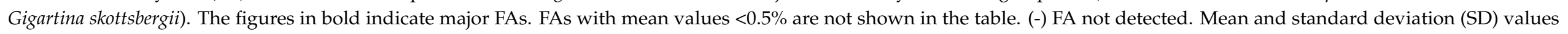
are presented.

\begin{tabular}{|c|c|c|c|c|c|c|c|c|c|c|c|}
\hline & \multicolumn{7}{|c|}{ Gondogeneia antarctica } & \multicolumn{4}{|c|}{ Red Algae } \\
\hline & Feb $(n=4)$ & $\operatorname{Mar}(n=3)$ & $\operatorname{Apr}(n=6)$ & May $(n=6)$ & Jun $(n=22)$ & $\mathrm{Jul}(n=3)$ & Oct $(n=13)$ & $\begin{array}{c}\text { Iridaea } \\
\text { cordata } \\
(n=4)\end{array}$ & $\begin{array}{c}\text { Palmaria } \\
\text { decipiens } \\
(n=3)\end{array}$ & $\begin{array}{c}\text { Gigartina } \\
\text { skottsbergii } \\
(n=3)\end{array}$ & $\begin{array}{l}\text { Curdiea } \\
\text { racovitzae } \\
(n=2)\end{array}$ \\
\hline $\begin{array}{l}\text { Total free FA } \\
\left(\mathrm{mg} \cdot \mathrm{g}^{-1} \mathrm{dw}\right) \\
\% \text { of FAs }\end{array}$ & $25.2 \pm 6.59$ & $35.6 \pm 14.7$ & $47.0 \pm 14.3$ & $60.5 \pm 22.1$ & $46.2 \pm 19.2$ & $50.2 \pm 12.1$ & $23.2 \pm 7.77$ & $60.6 \pm 10.5$ & $59.9 \pm 4.54$ & $63.2 \pm 1.78$ & $46.5 \pm 1.14$ \\
\hline C14:0 & $1.49 \pm 0.21$ & $2.85 \pm 0.71$ & $3.29 \pm 0.66$ & $4.89 \pm 1.01$ & $3.27 \pm 0.73$ & $3.2 \pm 0.73$ & $1.5 \pm 0.44$ & - & $0.22 \pm 0.38$ & - & $0.28 \pm 0.4$ \\
\hline $\mathrm{C} 16: 1(n-9)$ & $7.17 \pm 1.45$ & $8.41 \pm 2.67$ & $8.72 \pm 2.29$ & $\mathbf{1 0 . 3} \pm 4.76$ & $7.64 \pm 1.68$ & $8.48 \pm 2.51$ & $4.61 \pm 1$ & $0.95 \pm 1.09$ & $0.62 \pm 1.07$ & $0.24 \pm 0.05$ & $1.99 \pm 2.82$ \\
\hline C16:0 & $31.6 \pm 8.15$ & $33.6 \pm 7.93$ & $28.5 \pm 6.07$ & $29.5 \pm 8.68$ & $26.2 \pm 4.53$ & $26.7 \pm 6.59$ & $31.7 \pm 7.3$ & $31.8 \pm 4.55$ & $26.2 \pm 2.3$ & $42.7 \pm 2.7$ & $20.0 \pm 1.7$ \\
\hline C17:0 & $1.08 \pm 0.25$ & $1.03 \pm 0.27$ & $0.6 \pm 0.08$ & $0.7 \pm 0.08$ & $0.88 \pm 0.23$ & $0.67 \pm 0.25$ & $1.33 \pm 0.36$ & $4.21 \pm 1.64$ & $5.83 \pm 5.05$ & $0.56 \pm 0.04$ & $4.72 \pm 4.15$ \\
\hline $\mathrm{C} 18: 3(n-3)$ & $1.84 \pm 1.02$ & $1.45 \pm 0.79$ & $2.8 \pm 1.55$ & $3.06 \pm 1.4$ & $2.7 \pm 1.25$ & $4.07 \pm 0.4$ & $1.05 \pm 0.69$ & $1.52 \pm 0.45$ & $2.07 \pm 0.45$ & $1.21 \pm 0.25$ & $0.52 \pm 0.06$ \\
\hline $\mathrm{C} 18: 2(n-6)$ & $12.9 \pm 2.05$ & $14.9 \pm 2.05$ & $15.3 \pm 3.39$ & $\mathbf{1 4 . 1} \pm 4.14$ & $14.2 \pm 2.25$ & $10.6 \pm 2.95$ & $12.6 \pm 2.01$ & $2.21 \pm 1.12$ & $1.81 \pm 1.16$ & $0.81 \pm 0.07$ & $2.72 \pm 1.72$ \\
\hline $\mathrm{C} 18: 1(n-9)$ & $9.42 \pm 1.56$ & $9.87 \pm 1.54$ & $9.26 \pm 1.76$ & $9.3 \pm 2.97$ & $\mathbf{1 0 . 8} \pm 1.71$ & $7 \pm 2.97$ & $11.8 \pm 2.25$ & $24.9 \pm 3.64$ & $21.1 \pm 2.19$ & $\mathbf{9 . 3 1} \pm 0.7$ & $\mathbf{1 2 . 5} \pm 0.51$ \\
\hline $\mathrm{C} 18: 1(n-7)$ & $0.53 \pm 0.3$ & $0.47 \pm 0.1$ & $0.45 \pm 0.13$ & $1.25 \pm 1.03$ & $0.56 \pm 0.3$ & $0.25 \pm 0.23$ & $1.08 \pm 2.96$ & $1.11 \pm 0.48$ & $0.3 \pm 0.51$ & $0.22 \pm 0.04$ & $1.09 \pm 1.22$ \\
\hline C18:0 & $2.84 \pm 0.58$ & $2.31 \pm 0.29$ & $1.84 \pm 0.29$ & $1.44 \pm 0.73$ & $1.19 \pm 0.62$ & $1.5 \pm 0.34$ & $2.12 \pm 0.7$ & - & $0.47 \pm 0.82$ & - & - \\
\hline $\mathrm{C} 20: 5(n-3)$ & $19.4 \pm 10.4$ & $\mathbf{1 4 . 8} \pm 10.4$ & $17.3 \pm 8.2$ & $\mathbf{1 4 . 6} \pm 8.57$ & $\mathbf{1 7 . 4} \pm 9.33$ & $23.9 \pm 3.86$ & $18.2 \pm 9.33$ & $\mathbf{6 . 1 4} \pm 1.52$ & $\mathbf{1 1 . 8} \pm 1.39$ & $27.3 \pm 3.38$ & $27.8 \pm 3.91$ \\
\hline C20:4 (n-6) & $1.05 \pm 0.31$ & $0.67 \pm 0.17$ & $0.58 \pm 0.21$ & $0.57 \pm 0.18$ & $1.27 \pm 0.44$ & $1.46 \pm 0.03$ & $1.61 \pm 0.45$ & $\mathbf{1 0 . 0} \pm 1.46$ & $\mathbf{1 1 . 5} \pm 2.85$ & $\mathbf{1 1 . 4} \pm 1.51$ & $14.9 \pm 0.86$ \\
\hline C20:3 & $0.94 \pm 0.49$ & $0.77 \pm 0.39$ & $1.29 \pm 0.5$ & $1.23 \pm 0.29$ & $1.98 \pm 1.96$ & $1.63 \pm 0.08$ & $0.92 \pm 0.42$ & $1.45 \pm 0.32$ & $4.33 \pm 1.57$ & $0.41 \pm 0.03$ & $0.46 \pm 0.29$ \\
\hline C20:1 (n-9) & $1.3 \pm 0.12$ & $1.73 \pm 0.44$ & $2.63 \pm 0.94$ & $1.57 \pm 0.98$ & $1.68 \pm 0.75$ & $1.77 \pm 0.4$ & $1.44 \pm 0.4$ & $0.26 \pm 0.08$ & $0.77 \pm 0.25$ & $0.86 \pm 0.08$ & $1.49 \pm 0.83$ \\
\hline C21:0 & - & - & - & $0.05 \pm 0.11$ & $1.56 \pm 3.56$ & - & $0.16 \pm 0.44$ & $3.95 \pm 3.35$ & $0.59 \pm 0.56$ & $1.32 \pm 0.13$ & $2.53 \pm 0.89$ \\
\hline $\mathrm{C} 22: 6(n-3)$ & $3.99 \pm 2.65$ & $3.52 \pm 3.47$ & $4.74 \pm 3.01$ & $4.36 \pm 2.96$ & $4.86 \pm 2.36$ & $5.5 \pm 1.37$ & $4.19 \pm 1.82$ & $4.41 \pm 1.41$ & $4.9 \pm 2.17$ & $0.82 \pm 0.07$ & $4.08 \pm 1.4$ \\
\hline C22:0 & $1.78 \pm 0.59$ & $1.38 \pm 0.46$ & $0.9 \pm 0.24$ & $0.78 \pm 0.53$ & $0.8 \pm 0.55$ & $0.99 \pm 0.39$ & $1.88 \pm 0.67$ & - & - & - & - \\
\hline C23:0 & $0.97 \pm 0.32$ & $0.74 \pm 0.25$ & $0.49 \pm 0.15$ & $0.41 \pm 0.28$ & $0.4 \pm 0.24$ & $0.54 \pm 0.21$ & $0.97 \pm 0.42$ & - & - & - & - \\
\hline sum(\%) & 98.9 & 99.0 & 99.1 & 98.5 & 98.0 & 98.9 & 97.8 & 97.4 & 98.0 & 98.5 & 98.5 \\
\hline
\end{tabular}


Table 3. Results of SIMPER analyses of dissimilarities in the fatty acid (FA) composition between groups. Average dissimilarity (\%) and the most discriminant FAs are presented. Spring-summer (February and October), winter (March-July).

* data for benthic diatoms are from [13].

\begin{tabular}{ccc}
\hline Group & Dissimilarity (\%) & Most Discriminant FAs (\% Contribution) \\
\hline $\begin{array}{c}\text { Within Gondogeneia antarctica } \\
\text { Spring-summer vs. fall-winter }\end{array}$ & 21.6 & $20: 5(25) / 16: 0(20) / 16: 1(8.3) / 18: 2(7.0) / 18: 1(6.6) / 22: 6(6.3)$ \\
Gondogeneia antarctica vs. red algae & 35.8 & $18: 2(16) / 20: 4(15) / 16: 0(15) / 20: 5(14) / 18: 1(15) / 16: 1(5.9)$ \\
$\quad$ Spring-summer & 42.1 & $18: 1(15) / 18: 2(14) / 20: 5(14) / 20: 4(13) / 16: 1(9.3) / 16: 0(7.9)$ \\
$\quad$ Fall-winter & 57.3 & $16: 0(26) / 20: 5(16) / 18: 2(13) / 18: 1(12) / 14: 0(12) / 16: 1(5.8)$ \\
Gondogeneia antarctica vs. benthic diatom * & 56.4 & $16: 0(21) / 20: 5(18) / 18: 2(15) / 18: 1(10) / 14: 0(9.6) / 16: 1(9.4)$ \\
Spring-summer & &
\end{tabular}

The SIMPER analysis showed that the FAs contributing most to the dissimilarities in G. antarctica between the two contrasting seasons were C20:5 $5_{(n-3)}(25 \%)$ and C16:0 $(20 \%)$, followed by C16:1 $1_{(n-9)}(8.3 \%), \mathrm{C} 18: 2_{(n-6)}(7.0 \%), \mathrm{C} 18: 1_{(n-9)}(6.6 \%)$, and $\mathrm{C} 22: 6_{(n-3)}(6.3 \%)$. Of note, C20:5 $5_{(n-3)}$ increased to its highest value in July, in terms of both the absolute and relative compositions, while the other FAs decreased or changed slightly during the same period. The MDS plot showed that the FA composition of red algae was much closer to that of $G$. antarctica than the composition of benthic diatoms. The FA composition of benthic diatoms was distinct from $G$. antarctica.

\section{Discussion}

\subsection{Isotopic Signatures and Seasonal Dietary Shift of G. antarctica}

The isotopic dual plot (Figure 4) indicated a higher contribution of red algae to $G$. antarctica diet relative to the other sources investigated in the study. The G. antarctica $\delta^{13} \mathrm{C}$ values ( -18.9 to $-21.4 \%$ ) were close to the values of the 3 red algae (I. cordata -21.3 to $-22.3 \%$, P. decipiens -19.4 to $-20.5 \%$, and G. skottsbergii -21.1 to $-23.4 \%$ ) and benthic diatoms $(-23.3 \%)$, while the values were much heavier than those of SPOM $(-24.8 \%$ o to $-26.2 \%$ ) and brown algae (Desmarestia sp. $-27.3 \%$ and P. antarcticus $-32.0 \%$ ). It seemed that the red algae apparently contributed most to the G. antarctica diet throughout the investigation period, considering a fractionation factor of $0.8 \%$ in consumer $\delta^{13} \mathrm{C}$ relative to its diet $[59,70]$. The red algae are known to be palatable to many herbivores, detritivores and omnivores $[10,34,54-56]$. In particular, P. decipiens is the most preferred by G. antarctica $[10,56,71]$, and is one of the most common macroalgae in shallow waters adjacent to this study area and other similar environments around King George Island [22,53,72]. As reflected in the isotopic signatures, benthic diatoms seemed to partially contribute to the $G$. antarctica diet, while contribution of SPOM appears to be relatively small.

The G. antarctica $\delta^{13} \mathrm{C}$ and $\delta^{15} \mathrm{~N}$ values varied distinctly with seasonal variations in seawater temperature, salinity, and Chl- $a$ concentrations. However, the overall variation was small, indicating that the main diets of the amphipod, mainly red algae and partly benthic diatoms, did not change much throughout the year. The slight enrichment of $\delta^{13} \mathrm{C}$ in G. antarctica during the summer season (February-April) was likely due to increased availability of a fresh red algal diet. Around King George Island and the adjacent islands, the highest growth rates of these algal species were attained in austral spring (October-November) (P. decipiens) or summer (December) (I. cordata and G. skottsbergii), when the light conditions were most favorable for photosynthetic activities [24,73-75].

The G. antarctica isotopic values in this study were similar to those reported for the same species and other amphipod species in the WAP region [13,59]. Like other macroalgal grazers, the G. antarctica $\delta^{13} \mathrm{C}$ are heavier than the values of herbivorous suspension feeders whose diets are derived mainly from phytoplankton [76], and this is consistent with the result of this study that red algae are a primary carbon source in the G. antarctica diet. 
Thus, the results of this study revealed that the preference of G. antarctica for macroalgal diet persisted throughout much of the year. However, the G. antarctica $\delta^{15} \mathrm{~N}$ values maintained rather high $(6.3 \sim 7.5 \%$ o $)$ as for primary consumers, suggesting that dietary contribution from other food sources (e.g., crustacean parts and sponge spicules) $[9,10,13,34]$ should be considered in future studies.

\subsection{Contribution of Detrital Matter to the Gondogeneia antarctica Diet during the Fall-Winter}

Our results also suggest that degrading organic matter is an important food source for G. antarctica, particularly under subdued primary production during fall and winter. The $\delta^{15} \mathrm{~N}$ values increased significantly during the winter period in G. antarctica and its presumptive main diet, red algae, and also in macroalgae and SPOM (Figure 3). In particular, the SPOM $\delta^{15} \mathrm{~N}$ reached the peak values $(6.1 \pm 0.9 \%, n=21)$ in the winter season [June-September], which were two times higher than the values in the summer-early fall period [February-April] $(3.0 \pm 0.7 \%, n=11)$. This observation indicated that, during winter, a significant portion of the diet of G. antarctica is in the form of detritus, which was enriched with $\delta^{15} \mathrm{~N}$ through colonization and degradation by microbes, and sometimes also by protozoans and meiofauna [77-79].

After the growth peaks in spring-summer, macroalgal growth decrease during the fall and winter seasons around King George Island and the adjacent islands, particularly under the winter sea-ice cover, when light conditions for photosynthetic activities are unfavorable [24,73-75]. Therefore, fresh algal material is likely restricted in availability during fall-winter. G. antarctica is known to feed year-round [32,33], and there may be other alternative food sources for G. antarctica during this period. Macroalgal fragments seem to create a food bank for benthic communities in shallow Antarctic waters, as degradation processes by microbes may be slow due to low temperature $[79,80]$. Several studies have reported that a significant amount of carbon derived from macroalgal detritus enters the benthic food web in nearshore waters of the WAP [9,59,81-84].

Erosion and degradation of benthic macroalgae likely occur through several processes, such as mechanical abrasion by floating icebergs, tides, waves and storms, sea ice formation, and grazing $[81,84]$. Grazing by herbivores, such as amphipods, also promotes microbial degradation [79]. Almost all of the brown algae are unpalatable to grazers due to their chemical defenses and/or stiff texture [34,71]. However, brown algae can be palatable in detrital form [85].

Degrading macroalgal biomass seems to reach a peak in fall-early winter in King George Island, and to be consumed as a main diet by shallow-water herbivores like G. antarctica. In the adjacent Admiralty Bay, a large amount of decaying macroalgae were present on the shore in late April-early June, and the peak abundance and biomass of G. antarctica occurred during the same period [9]. In this study, we also observed a large accumulation of decaying macroalgae on the shore in April-May right before the sea water started to freeze (Figure 7). This observation supports the isotopic results; a significant portion of the diet of G. antarctica is in the form of detritus during the fall and winter periods. Benthic diatoms are also likely preserved as a food bank after summer blooms and utilized as alternative food sources to support benthic communities during winter $[80,86]$. In addition, sea ice may provide a habit for growth of epontic algae (mostly diatoms), which are grazed by herbivores like amphipods. Several studies reported that dense populations of adult and juvenile G. antarctica [33] and other amphipod species [32] were associated with micro-algal blooms under sea ice during mid-winter in the WAP. In the study area, the sea surface was frozen for about 3 months (late June through September) during the investigation period (Figure 2). 

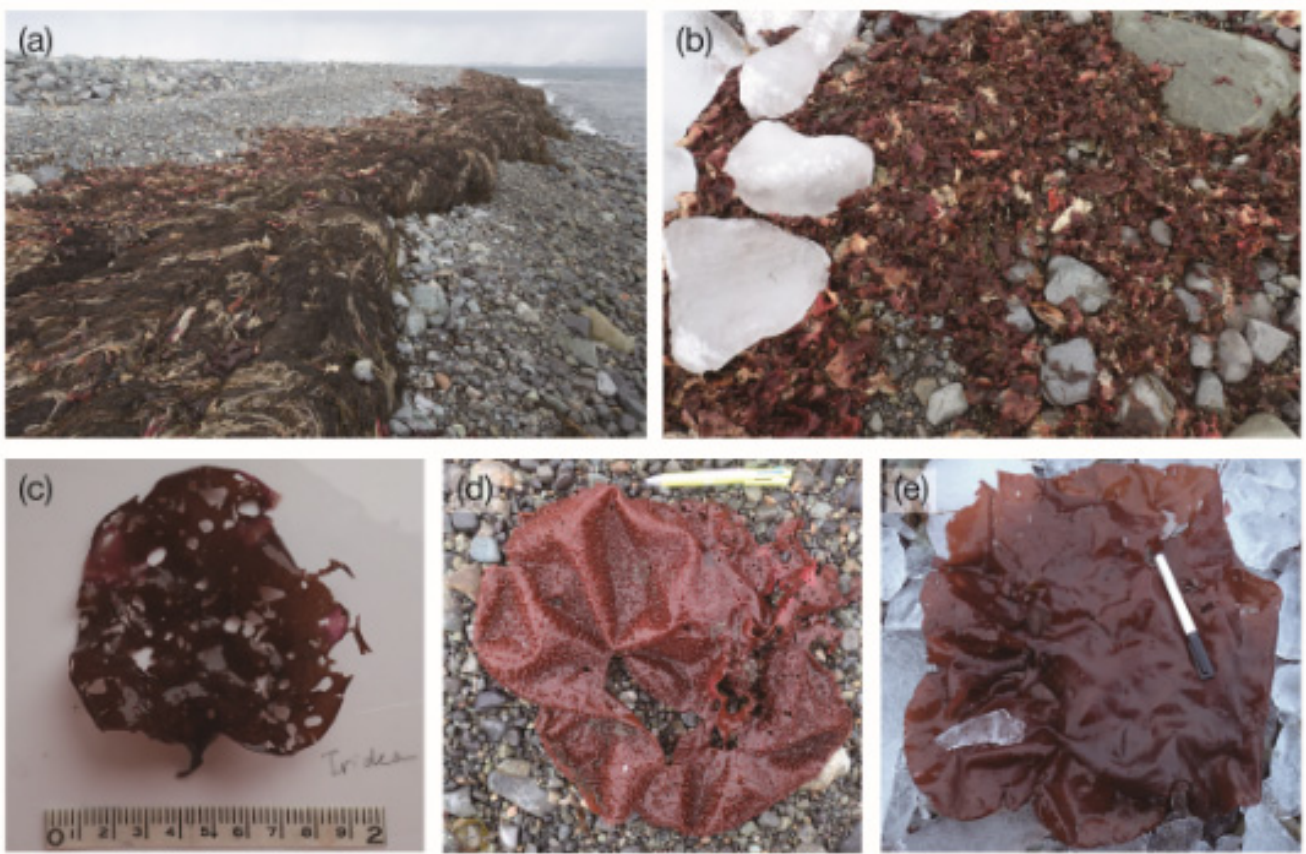

Figure 7. Macroalgal debris amassed on the shore of Marian Cove from April to early May 2015: (a) Mostly Desmarestia spp., (b) red algal fragments, (c) Iridaea cordata, (d) Gigartina skottsbergii, and (e) Curdiea racovitzae.

\subsection{FA Composition in Gondogeneia antarctica and Its Major Food Sources}

The FA results supported the isotopic results that the benthic primary producers, preferably red algae, contributed substantially to the G. antarctica diet throughout much of the year. The FA composition of G. antarctica showed small but distinct seasonal variation, particularly between the spring-summer and the fall-winter periods (Table 2, Figures 5 and 6). C20:5 $5_{(n-3)}$ and C16:0 collectively accounted for most $(45 \%)$ of the dissimilarity between the two contrasting periods (Table 3). The red algal FA composition was more similar to that of G. antarctica in spring-summer than winter (Figure 6, Table 3), indicating that fresh red algae were more available to the amphipod during this period.

Notably, C20:5 $(n-3)$ in G. antarctica increased to its highest value in July in terms of both the absolute and relative compositions, while the other FAs decreased or changed only slightly during the same period. The increase of $\mathrm{C} 20: 5_{(n-3)}$ in winter may be related, in part, to the increased contribution of benthic diatoms to the G. antarctica diet. A previous study reported that the gut contents and FA composition of G. antarctica reveal an important contribution of benthic diatoms [13]. It is well known that C20:5 $5_{(n-3)}$ occurs as a major FA in marine benthic diatoms and red algae [13,87], and has been used as a reliable dietary tracer in various marine benthic habitats from tropical to polar regions [88].

The FA composition of G. antarctica was similar to those of most Antarctic amphipods. Among the major FAs in G. antarctica, C16:0, C20:5 $5_{(n-3)}, \mathrm{C} 18: 1_{(n-9)}$, and C22:6 $6_{(n-3)}$ occur as major FAs in most amphipods in the peninsular region [13,89], and C16:0, C20:5 ${ }_{(n-3)}$, and $\mathrm{C} 18: 1_{(n-9)}$ were also the major FAs in the red algae analyzed in this and other studies [13]. In particular, $\mathrm{C} 20: 5_{(n-3)}$ and C16:0 predominated, constituting most $(41 \%-57 \%)$ of the FAs in this amphipod throughout the year.

Total FA content varied distinctly, with a peak seen in winter (Figure 5a). However, this pattern was unlikely to be related to variations in the diet, but rather to the reproductive cycle of G. antarctica, which is known to have two spawning peaks (at the end of February and at the end of September) [57]. We also observed some brooding individuals in July and early October samples, supporting the idea that reproductive development proceeded during the winter, contributing to the increase in total FA content. 


\subsection{Prospects for Climate Changes}

The WAP is rapidly warming and deglaciating under climate change [5]. The glacial retreats are opening up new habitats for marine benthic organisms [90], and sublittoral rocky substrates are increasingly colonized by macroalgae [91], seemingly providing more food for G. antarctica and other herbivores. In MC, Desmarestia spp. and the red alga Plocamium cartilagineum, species unpalatable to most herbivores, have increased significantly during the last 30 years, while P. decipiens, a species most preferred by G. antarctica, has decreased [53]. In addition, a recent study indicated that climate change could alter the biochemical composition of macroalgae, but not the feeding preference of G. antarctica [92]. Given that only a few macroalgal species are palatable to herbivores like G. antarctica, the decrease in the palatable algal population could affect the survival of this species, alter food-web structures, and eventually lead to ecosystem changes.

\section{Conclusions}

The SI and FA results in this study revealed that Gondogeneia antarctica rely substantially on food sources derived from benthic primary producers, mostly red algae and their detrital forms and partly benthic diatoms. However, the relatively high $\delta^{15} \mathrm{~N}$ values in G. antarctica, as for primary consumers, indicated additional dietary sources such as animal parts. The isotopic signatures varied with only small shifts seen throughout the year, indicating that contribution from the main dietary sources did not change much throughout the year. The overall results suggest that $G$. antarctica is not much affected by the extreme seasonality of pelagic primary production, and this strategy seems to have allowed G. antarctica to adapt successfully to shallow Antarctic nearshore waters. However, ongoing climate change is altering the distribution and biochemical composition of macroalgae favored by the amphipod, which could affect its adaptation and survival.

Author Contributions: I.-Y.A.: conceptualization, sample collection, data curation, writing of the original draft and editing, and project administration; F.E.-P.: conceptualization, methodology (sample analysis), data curation, and writing of the original draft; S.-Y.H.: methodology (sample analysis), data curation, and writing-review and editing; S.R.: writing-review and editing; D.U.K.: data curation and graphics. All authors have read and agreed to the published version of the manuscript.

Funding: This research was funded by the Korea Polar Research Institutes [grant nos. PE17070, PE 20120, and PE21110].

Acknowledgments: We thank Ji Hee Kim for identifying the macroalgal samples and Jong-Ku Gal for reviewing the manuscript.

Conflicts of Interest: The authors declare no conflict of interest.

\section{References}

1. Ducklow, H.W.; Fraser, W.R.; Meredith, M.P.; Stammerjohn, S.E.; Doney, S.C.; Martinson, D.G.; Sailley, S.F.; Schofield, O.M.; Steinberg, D.K.; Venables, H.J.; et al. West Antarctic Peninsula: An ice-dependent coastal marine ecosystem in transition. Oceanography 2013, 26, 190-203. [CrossRef]

2. Constable, A.J.; Melbourne-Thomas, J.; Corney, S.P.; Arrigo, K.R.; Barbraud, C.; Barnes, D.K.A.; Bindoff, N.; Boyd, P.; Brandt, A.; Costa, D.; et al. Climate change and Southern Ocean ecosystems I: How changes in physical habitats directly affect marine biota. Glob. Chang. Biol. 2014, 20, 3004-3025. [CrossRef] [PubMed]

3. Cauvy-Fraunie, S.; Dangles, O. A global synthesis of biodiversity responses to glacier retreat. Nature Ecol. Evol. 2019, 3, 1675-1685. [CrossRef]

4. Gutt, J.; Isla, E.; Xavier, J.C.; Adams, B.J.; Ahn, I.; Cheng, C.C.; Colesie, C.; Cummings, V.J.; di Prisco, G.; Griffiths, H.; et al. Antarctic ecosystems in transition-Life between stresses and opportunities. Boil. Rev. 2021, 96, 798-821. [CrossRef] [PubMed]

5. Cook, A.J.; Vaughan, D.G.; Luckman, A.J.; Murray, T. A new Antarctic Peninsula glacier basin inventory and observed area changes since the 1940s. Antarct. Sci. 2014, 26, 614-624. [CrossRef]

6. Smale, D.A.; Brown, K.M.; Barnes, D.K.; Fraser, K.P.; Clarke, A. Ice scour disturbance in Antarctic waters. Science 2008, 321,371 [CrossRef]

7. Barnes, D.K.A.; Souster, T. Reduced survival of Antarctic benthos linked to climate-induced iceberg scouring. Nat. Clim. Chang. 2011, 1, 365-368. [CrossRef] 
8. Barnes, D.K.A. Iceberg killing fields limit huge potential for benthic blue carbon in Antarctic shallows. Glob. Chang. Biol. 2017, 23, 2649-2659. [CrossRef]

9. Jażdżewski, K.; De Broyer, C.; Pudlarz, M.; Zielinski, D. Seasonal fluctuations of vagile benthos in the uppermost sublittoral of a maritime Antarctic fjord. Polar Biol. 2001, 24, 910-917. [CrossRef]

10. Huang, Y.M.; McClintock, J.B.; Amsler, C.D.; Peters, K.J.; Baker, B.J. Feeding rates of common Antarctic gammarid amphipods on ecologically important sympatric macroalgae. J. Exp. Mar. Biol. Ecol. 2006, 329, 55-65. [CrossRef]

11. Huang, Y.M.; Amsler, M.O.; McClintock, J.B.; Amsler, C.D.; Baker, B.J. Patterns of gammaridean amphipod abundance and species composition associated with dominant subtidal macroalgae from the western Antarctic Peninsula. Polar Biol. 2007, 30 , 1417-1430. [CrossRef]

12. Aumack, C.F.; Amsler, C.D.; Mcclintock, J.B.; Baker, B.J. Changes in amphipod densities among macroalgal habitats in day versus night collections along the Western Antarctic Peninsula. Mar. Biol. 2011, 138, 1879-1885. [CrossRef]

13. Aumack, C.F.; Lowe, A.T.; Amsler, C.D.; Amsler, M.O.; McClintock, J.B.; Baker, B.J. Gut content, fatty acid, and stable isotope analyses reveal dietary sources of macroalgal-associated amphipods along the western Antarctic Peninsula. Polar Biol. 2017, 40, 1371-1384. [CrossRef]

14. Jażdżewska, A.M.; Siciński, J. Assemblages and habitat preferences of soft bottom Antarctic amphipoda: Admiralty Bay case study. Polar Biol. 2017, 40, 1845-1869. [CrossRef]

15. Elias-Piera, F.; Rossi, S.; Petti, M.A.V.; Campos, L.S.; Valério-Berardo, M.T.; Corbisier, T.N. Faunal associated with morphologically distinct macoralgae from Admiralty Bay, King George Island (Antarctica). Polar Biol. 2020, 43, 1535-1547. [CrossRef]

16. De Broyer, C.; Lowry, J.K.; Jażdżewski, K.; Robert, H. Catalogue of the Gammaridean and Corophiidean Amphipoda (Crustacea) of the Southern Ocean with distribution and ecological data. Bull. Inst. R Sci. Nat. Belg. Biol. 2007, 77, 1-325.

17. Jażdżewski, K.; Teodorczyk, W.; De Broyer, C.; Konopacka, A. Survey and distributional patterns of the amphipod fauna of Admiralty Bay, King George Island, South Shetland Islands. Pol. Polar Res. 1991, 12, 461-472.

18. Jażdżewski, K.; Teodorczyk, W.; Siciński, J.; Kontek, B. Amphipod crustaceans as an important component of zoobenthos of the shallow Antarctic sublittoral. Hydrobiologia 1991, 223, 105-117. [CrossRef]

19. Dauby, P.; Scailteur, Y.; De Broyer, C. Trophic diversity within the eastern Weddell Sea amphipod community. Hydrobiologia 2001, 443, 69-86. [CrossRef]

20. Nyssen, F.; Brey, T.; Lepoint, G.; Bouquegneau, J.-M.; De Broyer, C.; Dauby, P. A stable isotope approach to the eastern Weddell Sea trophic web: Focus on benthic amphipods. Polar Biol. 2002, 25, 280-287. [CrossRef]

21. Nyssen, F.; Brey, T.; Dauby, P.; Graeve, M. Trophic position of Antarctic amphipods—Enhanced analysis by a 2-dimensional biomarker assay. Mar. Ecol. Prog. Ser. 2005, 300, 135-145. [CrossRef]

22. Oliveira, E.C.; Absher, T.M.; Pellizzari, F.M.; Oliveira, M.C. The seaweed flora of Admiralty Bay, King George Island, Antarctic. Polar Biol. 2009, 32, 1639-1647. [CrossRef]

23. Jażdżewska, A.M. Soft bottom sublittoral amphipod fauna of Admiralty Bay, King George Island, Antarctic. Oceanol. Hydrobiol. Stud. 2011, 40, 1-10. [CrossRef]

24. Wiencke, C.; Amsler, C.D. Chapter 13 Seaweeds and Their Communities in Polar Regions. In Seaweed Biology; Wiencke, D., Bischof, K., Eds.; Springer: Berlin/Heidelberg, Germany, 2012; pp. 265-291.

25. Kim, J.-H.; Jażdżewska, A.; Choi, H.-G.; Kim, W. The first report on Amphipoda from Marian Cove, King George Island, Antarctic. Oceanol. Hydorbiol. Stud. 2014, 43, 106-113. [CrossRef]

26. Barrera-Oro, E.R.; Moreira, E.; Seefeldt, M.A.; Francione, M.V.; Quartino, M.L. The importance of macroalgae and associated amphipods in the selective benthic feeding of sister rockcod species Notothenia rossii and N. coriiceps (Nototheniidae) in West Antarctica. Polar Biol. 2019, 42, 317-334. [CrossRef]

27. Gilles, C.L.; Stark, J.S.; Johnstone, G.J.; Smith, S.D.A. Carbon flow and trophic structure of an Antarctic coastal benthic community as determined by d13C and d15N. Estuar. Coast. Shelf Sci. 2012, 97, 44-57. [CrossRef]

28. Pasotti, F.; Saravia, L.A.; De Troch, M.; Tarantelli, M.S.; Sahade, R.; Vamreisel, A. Benthic trophic interactions in an Antarctic shallow water ecosystem affected by recent glacier retreat. PLoS ONE 2015, 10, e0141742. [CrossRef]

29. Servetto, N.; Rossi, S.; Fuentes, V.; Alurralde, G.; Lagger, C.; Sahade, R. Seasonal trophic ecology of the dominant Antarctic coral Malacobelemnon daytoni (Octacorallia, Pennatulacea, Kophobelemnidae). Mar. Environ. Res. 2017, 130, 264-274. [CrossRef]

30. Ha, S.-Y.; Ahn, I.-Y.; Moon, H.-W.; Choi, B.; Shin, K.-H. Tight trophic association between benthic diatom blooms and shallowwater megabenthic communities in a rapidly deglaciated Antarctic fjord. Estuar. Coast. Shelf Sci. 2019, 218, 258-267. [CrossRef]

31. Zenteno, I.; Cárdenas, I.; Valdivia, N.; Gómez, I.; Höfer, J.; Garrido, I.; Pardo, I.M. Unraveling the multiple bottom-up supplies of an Antarctic nearshore benthic community. Prog. Oceanogr. 2019, 174, 55-63. [CrossRef]

32. Richardson, M.G.; Whitaker, T.M. An Antarctic fast-ice food chain: Observations on the interaction of the amphipod Pontogeneia antarctica Chevreux with ice-associated microalgae. Bull. Br. Antarct. Surv. 1979, 47, 107-115.

33. Momo, F.R. Life Cycle and Spatial Distribution of Gondogeneia antarctica Chevreux (Crustacea, Amphipoda). Ph.D. Thesis, Universidad de Buenos Aires, Buenos Aires, Argentina, 1995. (In Spanish).

34. Amsler, C.; Iken, K.; McClintock, J.; Amsler, M.; Peters, K.; Hubbard, J.; Furrow, F.; Baker, B. Comprehensive evaluation of the palatability and chemical defenses of subtidal macroalgae from the Antarctic Peninsula. Mar. Ecol. Prog. Ser. 2005, 294, 141-159. [CrossRef] 
35. Duarte, W.E.; Moreno, C.A. The specialized diet of Harpagifer bispinis: Its effect on the diversity of Antarctic intertidal amphipods. Hydrobiologia 1981, 80, 241-250. [CrossRef]

36. Creet, S.; Van Franeker, J.A.; Van Spanje, T.M.; Wolff, W.J. Diet of the Pintado petrel Daption capense at King George Island, Antarctica, 1990/91. Mar. Ornithol. 1994, 22, 221-229.

37. Fanta, E. Laboratory tests on feeding interactions and food preferences of some Antarctic fish from Admiralty Bay, King George Island, South Shetland Islands. Pol. Polar Res. 1999, 20, 335-346.

38. Barrera-Oro, E.R.; Piacentino, G.L.M. Feeding habits of juvenile Trematomus newnesi (Pisces, Nototheniidae) at Potter Cove, South Shetland Islands, Antarctica. Polar Biol. 2007, 30, 789-796. [CrossRef]

39. Barrera-Oro, E.R.; Winter, D.J. Age composition and feeding ecology of early juvenile Notothenia rossii (Pisces, Nototheniidae) at Potter Cove, South Shetland Islands, Antarctica. Antarct. Sci. 2008, 20, 339-341. [CrossRef]

40. Marina, T.I.; Salinas, V.; Cordone, G.; Campana, G.; Moreira, E.; Deregibus, D.; Torre, L.; Sahade, R.; Tatián, M.; Oro, E.B.; et al. The food web of Potter Cove (Antarctica): Complexity, structure and function. Estuar Costal Shelf Sci. 2018, 200, 141-151. [CrossRef]

41. Arrigo, K.R.; Worthen, D.; Schnell, A.; Lizotte, M.P. Primary production in Southern Ocean waters. J. Geophys. Res. 1998, 103, 15587-15600. [CrossRef]

42. Kim, D.-U.; Khim, J.S.; Ahn, I.-Y. Patterns, drivers and implications of ascidian distributions in a rapidly deglaciating fjord, King George Island, West Antarctic Peninsula. Ecol. Indic. 2021, 125, 107467. [CrossRef]

43. Chang, K.I.; Jun, H.K.; Park, G.T.; Eo, Y.S. Oceanographic conditions of Maxwell Bay, King George Island, Antarctica (austral summer 1989). Korean J. Polar Res. 1990, 1, 27-46.

44. Yoo, K.-C.; Lee, M.K.; Yoon, H.I.; Lee, Y.I.; Kang, C.Y. Hydrography of Marian Cove, King George Island, West Antarctica: Implications for ice-proximal sedimentation during summer. Antarct. Sci. 2015, 27, 185-196. [CrossRef]

45. Moon, H.W.; Wan Hussin, W.M.R.; Kim, H.C.; Ahn, I.Y. The impacts of climate change on Antarctic nearshore mega-epifaunal benthic assemblages in a glacial fjord on King George Island: Responses and implications. Ecol. Indic. 2015, 57, $280-292$. [CrossRef]

46. Yoon, H.I.; Park, B.K.; Domack, E.W.; Kim, Y. Distribution and dispersal pattern of suspended particulate matter in Maxwell Bay and its tributary, Marian Cove, in the South Shetland Islands, West Antarctica. Mar. Geol. 1998, 152, 261-275. [CrossRef]

47. Yoo, K.; Yoon, H.; Oh, J.; Kim, Y.; Kang, C. Water column properties and dispersal pattern of suspended particulate matter (SPM) of Marian Cove during austral summer, King George Island, West Antarctica. J. Korean Soc. Oceanogr. 1999, 4, $266-274$.

48. Yoo, K.; Kang, C.; Yoon, H.; Suk, D.; Oh, J. Seasonal water column properties and dispersal pattern of suspended particulate matter (SPM) in Marian Cove, King George Island, South Shetland Islands. J. Korean Soc. Oceanogr. 2002, 38, 573-593.

49. Ahn, I.Y.; Chung, K.H.; Choi, H.J. Influence of glacial runoff on baseline metal accumulation in the Antarctic limpet Nacella concinna from King George Island. Mar. Pollut. Bull. 2004, 49, 119-127. [CrossRef]

50. Chung, H.; Oh, Y.S.; Lee, I.K.; Kim, D.Y. Macroalgal vegetation of Maxwell Bay in King George Island, Antarctica. Korean J. Phycol. 1994, 9, 47-58.

51. Kim, J.H.; Chung, H.; Oh, Y.S.; Lee, I.K. Macroalgal flora of Maxwell Bay, King George Island, Antarctica: I. Chlorophyta, Chrysophyta and Phaeophyta. Ocean. Polar Res. 2001, 23, 209-221.

52. Kim, J.H.; Chung, H.; Oh, Y.S.; Lee, I.K. Macroalgal flora of Maxwell Bay, King George Island, Antarctica: II. Rhodophyta. Ocean. Polar Res. 2001, 23, 347-360.

53. Ko, Y.W.; Choi, H.-G.; Lee, D.S.; Kim, J.H. 30 years revisit survey for long-term changes in the Antarctic subtidal algal assemblage. Sci. Rep. 2020, 10, 8481. [CrossRef]

54. Iken, K.; Barrera-Oro, E.R.; Quartino, M.L.; Casaux, R.J.; Brey, T. Grazing by the Antarctic fish Notothenia coriiceps: Evidence for selective feeding on macroalgae. Antarct. Sci. 1997, 9, 386-391. [CrossRef]

55. Iken, K.; Quartino, M.; Wiencke, C. Histological identification of macroalgae from stomach contents of the Antarctic fish Notothenia coriiceps using semi-thin sections. Mar. Ecol. 1999, 20, 11-17. [CrossRef]

56. Bucolo, P.; Amsler, C.D.; McClintock, J.B.; Baker, B.J. Palatability of the Antarctic rhodophyte Palmaria decipiens (Reinsch) RW Ricker and its endo/epiphyte Elachista antarctica Skottsberg to sympatric amphipods. J. Exp. Mar. Biol. Ecol. 2011, 396, 202-206. [CrossRef]

57. Doyle, S.R.; Momo, F.R.; Brêthes, J.C.; Ferreyra, G.A. Metabolic rate and food availability of the Antarctic amphipod Gondogeneia antarctica (Chevreux 1906): Seasonal variation in allometric scaling and temperature dependence. Polar Biol. 2012, 35, 413-424. [CrossRef]

58. Ahn, I.Y.; Moon, H.W.; Jeon, M.; Kang, S.H. First record of massive blooming of benthic diatoms in their association with megabenthic filter feeders on the shallow seafloor of an Antarctic fjord: Does glacier melting fuel the bloom? Ocean Sci. J. 2016, 51, 273-279. [CrossRef]

59. Dunton, K.H. $\delta^{13} \mathrm{C}$ and $\delta^{15} \mathrm{~N}$ measurements of Antarctic Peninsula fauna: Trophic relationships and assimilation of benthic seaweeds. Am. Zool. 2001, 41, 99-112. [CrossRef]

60. Ahn, I.Y.; Chung, H.; Kang, J.S.; Kang, S.H. Diatom composition and biomass variability in nearshore waters of Maxwell Bay, Antarctica during the 1992/1993 austral summer. Polar Biol. 1997, 17, 123-130. [CrossRef]

61. Choy, E.J.; Park, H.; Kim, J.H.; Ahn, I.Y.; Kang, C.K. Isotopic shift for defining habitat exploitation by the Antarctic limpet Nacella concinna from rocky coastal habitats (Marian Cove, King George Island). Estuar. Coast. Shelf Sci. 2011, 92, 339-346. [CrossRef] 
62. Jacob, U.; Brey, T.; Fetzer, I.; Kaehler, S.; Mintenbeck, K.; Dunton, K.; Beyer, K.; Struck, U.; Pakhomov, E.; Arntz, W.E. Towards the trophic structure of the Bouvet Island marine ecosystem. Polar Biol. 2005, 29, 106-113. [CrossRef]

63. Bunn, S.E.; Loneragan, N.R.; Kempster, M.A. Effects of Acid Washing on Stable Isotope Ratios of C and N in Penaeid Shrimp and Seagrass: Implications for Food-Web Studies Using Multiple Stable Isotopes. Limnol. Oceanogr. 1995, 40, 622-625. [CrossRef]

64. Logan, J.M.; Lutcavage, M.E. A comparison of carbon and nitrogen stable isotope ratios of fish tissues following lipid extractions with non-polar and traditional chloroform/methanol solvent systems. Rapid Commun. Mass Spectrom. 2008, 22, $1081-1086$. [CrossRef]

65. Soler-Membives, A.; Rossi, S.; Munilla, T. Feeding ecology of Ammothella longipes (Arthropoda: Pycnogonida) in the Mediterranean Sea: A fatty acid biomarker approach. Estuar. Coast. Shelf Sci. 2011, 92, 588-597. [CrossRef]

66. Gori, A.; Rossi, S.; Linares, C.; Berganzo, E.; Orejas, C.; Dale, M.R.T.; Gili, J.M. Size and spatial structure in deep versus shallow populations of the Mediterranean gorgonian Eunicella singularis (Cap de Creus, northweste.rn Mediterranean Sea). Mar. Biol. 2011, 158, 1721-1732. [CrossRef]

67. Viladrich, N.; Bramanti, L.; Tsounis, G.; Chocarro, B.; Martínez-Quintana, A.; Ambroso, S.; Madurell, T.; Rossi, S. Energetic resource allocation in reproduction for two temperate octocorals with contrasting reproductive strategies: Surface versus internal brooder. Coral Reefs 2016, 35, 1033-1045. [CrossRef]

68. Clarke, K.R.; Gorley, R.N. PRIMER 6 User Manual/Tutorial; PRIMER-E Ltd.: Plymouth, UK, 2006.

69. KOPRI. Overwintering Report of the Antarctic King Sejong Station 28th Overwintering Party (December 2014-December 2015); Korea Polar Research Institute: Incheon, Korea, 2016; p. 881.

70. DeNiro, M.J.; Epstein, S. Influence of diet on the distribution of carbon isotopes in animals. Geochim. Cosmochim Acta 1978, 42, 495-506. [CrossRef]

71. Aumack, C.F.; Amsler, C.D.; Mcclintock, J.B.; Baker, B.J. Chemically mediated resistance to mesoherbivory in finely branched macroalgae along the western Antarctic Peninsula. Eur. J. Phycol. 2010, 45, 19-26. [CrossRef]

72. Quartino, M.L.; Boraso de Zaixso, A.L. Summer macroalgal biomass in Potter Cove, South Shetland Islands, Antarctica: Its production and flux to the ecosystem. Polar Biol. 2008, 31, 281-294. [CrossRef]

73. Wiencke, C. Seasonality of Red and Green Macroalgae from Antarctica-A Long-Term Culture Study under Fluctuating Antarctic Daylengths. Polar Biol. 1990, 10, 601-607. [CrossRef]

74. Weykam, G.; Wiencke, C. Seasonal photosynthetic performance of the endemic antarctic red alga Palmaria decipiens (Reinsch) Ricker. Polar Biol. 1996, 16, 357-361. [CrossRef]

75. Weykam, G.; Thomas, D.N.; Wiencke, C. Growth and photosynthesis of the Antarctic red algae Palmaria decipiens (Palmariales) and Iridaea cordata (Gigartinales) during and following extended periods of darkness. Phycologia 1997, 36, 395-405. [CrossRef]

76. Dunton, K.H.; Schell, D.M. Dependence of consumers on macroalgal (Laminaria solidungula) carbon in an arctic kelp community: $\delta^{13}$ C evidence. Mar. Biol. 1987, 93, 615-625. [CrossRef]

77. Mintenbeck, K.; Jacob, U.; Knust, R.; Arntz, W.E.; Brey, T. Depth-dependence in stable isotope ratio $\delta^{15} \mathrm{~N}$ of benthic POM consumers: The role of particle dynamics and organism trophic guild. Deep Sea Res. 2007, 54, 1015-1023. [CrossRef]

78. Roy, V.; Iken, K.; Gosselin, M.; Tremblay, J.É.; Bélanger, S.; Archambault, P. Benthic faunal assimilation pathways and depth-related changes in food-web structure across the Canadian Arctic. Deep Sea Res. 2015, 102, 55-71. [CrossRef]

79. Braeckman, U.; Pasotti, F.; Vázquez, S.; Zacher, K.; Hoffmann, R.; Elvert, M.; Marchant, H.; Buckner, C.; Quartino, M.L.; Mác Cormack, W.; et al. Degradation of macroalgal detritus in shallow coastal Antarctic sediments. Limnol. Oceanogr. 2019, 64, 1423-1441. [CrossRef] [PubMed]

80. Mincks, S.; Smith, C.R.; DeMaster, D.J. Persistence of labile organic matter and microbial biomass in Antarctic shelf sediments: Evidence of a sediment 'food bank'. Mar. Ecol. Prog. Ser. 2005, 300, 3-19. [CrossRef]

81. Fischer, G.; Wiencke, C. Stable carbon isotope composition, depth distribution and fate of macroalgae from the Antarctic Peninsula region. Polar Biol. 1992, 12, 341-348. [CrossRef]

82. Corbisier, T.N.; Petti, M.A.V.; Skowronski, R.S.P.; Brito, T.A.S. Trophic relationships in the nearshore zone of Martel Inlet (King George Island, Antarctica): d13C stable-isotope analysis. Polar Biol. 2004, 27, 75-82. [CrossRef]

83. Kaehler, S.; Pakhomov, E.A.; Kalin, R.M.; Davis, S. Trophic importance of kelp-derived suspended particulate matter in a through-flow sub-Antarctic system. Mar. Ecol. Prog. Ser. 2006, 316, 17-22. [CrossRef]

84. Lastra, M.; Rodil, I.F.; Sánchez-Mata, A.; García-Gallego, M.; Mora, J. Fate and processing of macroalgal wrack subsidies in beaches of Deception Island, Antarctic Peninsula. J. Sea Res. 2014, 88, 1-10. [CrossRef]

85. Amsler, C.D.; McClintock, J.B.; Baker, B.J. Palatability of living and dead detached Antarctic macroalgae to consumers. Antarct. Sci. 2012, 24, 589-590. [CrossRef]

86. Ziegler, A.F.; Cape, M.; Lundesgaard, Ø.; Smith, C.R. Intense deposition and rapid processing of seafloor phytodetritus in a glaciomarine fjord, Andvord Bay (Antarctica). Prog. Oceanogr. 2020, 187, 102413. [CrossRef]

87. Dunstan, G.A.; Volkman, J.K.; Barrett, S.M.; Leroi, J.-M.; Jeffrey, S.W. Essential polyunsaturated fatty acids from 14 species of diatom (bacillariophyceae). Phytochemistry 1994, 35, 155-161. [CrossRef]

88. Kelly, J.; Scheibling, R. Fatty acids as dietary tracers in benthic food webs. Mar. Ecol. Prog. Ser. 2012, 446, 1-22. [CrossRef]

89. Graeve, M.; Dauby, P.; Scailteur, Y. Combined lipid, fatty acid and digestive tract content analyses: A penetrating approach to estimate feeding modes of Antarctic amphipods. Polar Biol. 2001, 24, 853-862. 
90. Lagger, C.; Nime, M.; Torre, L.; Servetto, N.; Tatián, M.; Sahade, R. Climate change, glacier retreat and a new ice-free island offer new insights on Antarctic benthic responses. Ecography 2018, 41, 579-591. [CrossRef]

91. Quartino, M.L.; Deregibus, D.; Campana, G.L.; Latorre, G.E.J.; Momo, F.R. Evidence of macroalgal colonization on newly ice-free areas following glacial retreat in Potter Cove (South Shetland Islands), Antarctica. PLoS ONE 2013, 8, e58223. [CrossRef]

92. Schram, J.B.; Schoenrock, K.M.; McClintock, J.B.; Amsler, C.D.; Angus, R.A. Ocean warming and acidification alter Antarctic macroalgal biochemical composition but not amphipod grazer feeding preferences. Mar. Ecol. Prog. Ser. 2017, 581, 45-56. [CrossRef] 